\title{
Mechanisms for decadal scale variability in a simulated Atlantic meridional overturning circulation
}

\author{
I. Medhaug $\cdot$ H. R. Langehaug $\cdot$ T. Eldevik $\cdot$ \\ T. Furevik $\cdot$ M. Bentsen
}

Received: 16 February 2011/ Accepted: 14 June 2011/Published online: 25 June 2011

(C) The Author(s) 2011. This article is published with open access at Springerlink.com

\begin{abstract}
Variability in the Atlantic Meridional Overturning Circulation (AMOC) has been analysed using a 600-year pre-industrial control simulation with the Bergen Climate Model. The typical AMOC variability has amplitudes of 1 Sverdrup $\left(1 \mathrm{~Sv}=10^{6} \mathrm{~m}^{3} \mathrm{~s}^{-1}\right)$ and time scales of 40-70 years. The model is reproducing the observed dense water formation regions and has very realistic ocean transports and water mass distributions. The dense water produced in the Labrador Sea (1/3) and in the Nordic Seas, including the water entrained into the dense overflows across the Greenland-Scotland Ridge (GSR; 2/3), are the sources of North Atlantic Deep Water (NADW) forming the lower limb of the AMOC's northern overturning. The variability in the Labrador Sea and the Nordic Seas convection is driven by decadal scale air-sea fluxes in the convective region that can be related to opposite phases of the North Atlantic Oscillation. The Labrador Sea convection is directly linked to the variability in AMOC. Linkages between convection and water mass transformation in the Nordic Seas are more indirect. The Scandinavian Pattern, the third mode of atmospheric variability in the North
\end{abstract}

I. Medhaug ( $\square)$. T. Eldevik · T. Furevik

Geophysical Institute, University of Bergen,

Allegaten 70, 5007 Bergen, Norway

e-mail: Iselin.Medhaug@gfi.uib.no

I. Medhaug - H. R. Langehaug - T. Eldevik - T. Furevik ·

M. Bentsen

Bjerknes Centre for Climate Research, Bergen, Norway

H. R. Langehaug

Nansen Environmental and Remote Sensing Center,

Bergen, Norway

M. Bentsen

Uni Bjerknes Centre, Uni Research, Bergen, Norway
Atlantic, is a driver of the ocean's poleward heat transport (PHT), the overall constraint on northern water mass transformation. Increased PHT is both associated with an increased water mass exchange across the GSR, and a stronger AMOC.

Keywords Decadal variability - Atlantic Meridional Overturning Circulation - Deep water formation .

Water mass transformations - Convection

\section{Introduction}

The Atlantic Meridional Overturning circulation (AMOC) is wind- and density driven with northward flowing surface water in the North Atlantic Current, buoyancy loss and sinking in the north, and southward flowing North Atlantic Deep Water (NADW) at depth. The circulation is closed as NADW is gradually brought to the surface by low latitude diapycnal mixing as well as wind-driven upwelling in the Southern Ocean (Kuhlbrodt et al. 2007). Further below there is a weaker and reversed overturning cell associated with the northward spreading of the denser Antarctic Bottom Water, which gradually mixes with the southward flowing NADW above (e.g., Ganachaud and Wunsch 2000; Johnson 2008).

While surface water is flowing from low to high latitudes, it gradually looses buoyancy due to cooling. The effect is partly compensated by freshening from river runoff, precipitation and ice melt. The lowering of the centre of mass represents a loss in potential energy. Without energy input, the deep ocean would turn into a stagnant pool of dense water within the order of thousand years (Munk and Wunsch 1998). The energy needed to drive the AMOC comes from winds and tides gradually 
mixing deep and dense water masses with lighter waters above and thus increasing the potential energy (Munk and Wunsch 1998; Wunsch 2002; Gade and Gustafsson 2004; Kuhlbrodt et al. 2007). Using wind and satellite altimetry products (e.g., Egbert and Ray 2000) the spatial variations in the energy input can be estimated, but little is known about how this energy input is varying on decadal and longer time scales, and to what extent and on which time scales such variations can influence the overturning.

Due to its linkages with the northward heat transport and the climate of the North Atlantic region (e.g., Vellinga and Wood 2002; McManus et al. 2004; Rhines et al. 2008), AMOC variability is a key constraint on observed or projected climate change. The majority of the state-of-the-art climate models show a weakening in the AMOC throughout the 21st century when they are forced with increasing atmospheric greenhouse gas concentrations (e.g., Gregory et al. 2005; Meehl et al. 2007; Medhaug and Furevik 2011). In the models warming and freshening in the north reduce the buoyancy loss and weaken the rate of water mass transformation. While the models agree on the sign of the changes they do not agree on the relative importance of the change in heat and freshwater fluxes for the weakening of the AMOC. There are at present no observations indicating whether such a decrease in overturning rate is already taking place (e.g., Cunningham et al. 2007; Cunningham and Marsh 2010). On the contrary, high-resolution modelling (Biastoch et al. 2008) and combined satellite altimetry and in situ observations (Willis 2010) hint to a weak upward trend in overturning circulation during the last decades.

The North Atlantic Ocean (see overview map in Fig. 1) has two main source regions for deep water: The Labrador Sea/Irminger Sea and the Nordic Seas (Clarke and Gascard 1983; Dickson and Brown 1994; Hansen and Østerhus 2000; Pickart et al. 2003). Surface cooling, and in some shelf regions brine release due to ice freezing, make the relatively saline North Atlantic water sufficiently dense to form the NADW.

From direct current measurements and water mass properties, Dickson and Brown (1994) estimated that around one-third of the total NADW originates from water spilling over the Greenland-Scotland Ridge, one-third is due to entrainment of ambient water when this water is cascading downwards south of the sill, and the final third originates in the Labrador Sea.

Due to its potential great importance for North Atlantic climate, improved knowledge of the mechanisms for the variability in AMOC will improve the understanding and simulation of present and upcoming climate variability. This includes detection and attribution of anthropogenic climate change, the origins for the discrepancies between models and observations, and the construction of

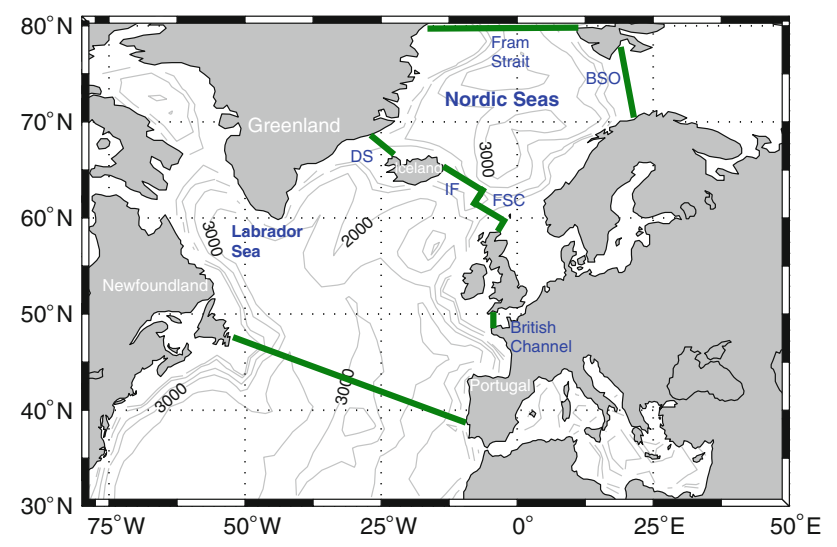

Fig. 1 Bathymetry of the North Atlantic-Nordic Seas region. Green sections show the Fram Strait, Barents Sea opening (BSO), the Greenland-Scotland Ridge (GSR) and the British Channel enclosing the Nordic Seas, and the Newfoundland section in the North Atlantic. Openings on the GSR are indicated by the Denmark Strait (DS), Iceland-Faroe Ridge (IF) and Faroe-Shetland Channel (FSC)

observational schemes for initialising future decadal climate prediction systems.

The aim of this work is to identify mechanisms for the low frequency changes in the Atlantic Meridional Overturning Circulation (AMOC) in the Bergen Climate Model (Otterå et al. 2009, 2010) and compare with what is known from observations. Previously suggested candidates for AMOC variability are oceanic response to aggregated atmospheric white noise forcing at high northern latitudes where dense water is produced (e.g., Dickson et al. 1996; Häkkinen 1999; Delworth and Greatbatch 2000; Eden and Willebrand 2001; Deshayes and Frankignoul 2008), a pure oceanic mode associated with advection of density anomalies (e.g., Delworth et al. 1993; Jungclaus et al. 2005), or a coupled atmosphere-ocean mode which in some models includes sea ice variability (e.g., Holland et al. 2001; Bentsen et al. 2004; Biastoch et al. 2008).

The layout of this paper is as follows. Section 2 contains a brief model description with the formulation of mixed layer and convection dynamics, and the statistical methods used in the analysis. The dense water formation regions are identified and the driving mechanisms for the decadal to multidecadal changes of the AMOC are presented in Sect. 3 and discussed in Sect. 4. Summary and concluding remarks are given in Sect. 5.

\section{The coupled Bergen climate model}

\subsection{Model description}

The model output being used for this study is a 600-year long simulation after the spin-up phase of the pre-industrial 
control climate with the Bergen Climate Model (BCM), a fully coupled atmosphere-ocean-sea ice general circulation model. A general description of the model can be found in Furevik et al. (2003), with more recent updates given in Otterå et al. (2009). Only a brief overview of the model system will be given here.

The model consists of the ocean model MICOM (Miami Isopycnic Coordinate Ocean Model; Bleck et al. 1992) coupled with the atmospheric model ARPEGE/IFS (Action de Recherche Petite Echelle Grande Echelle/Integrate Forecast System; Déqué et al. 1994). A dynamic-thermodynamic sea ice model (GELATO; Salas-Mélia 2002) is included. The model uses no flux correction, and is therefore free to evolve its own climatology. The only constraint is the incoming solar radiation at the top of the atmosphere.

ARPEGE is configured with a spectral truncation of wave number $\left(T_{L} 63\right)$ on a linear grid. The physical resolution is approximately $2.8^{\circ}$ along the Equator and a total of 31 vertical levels are used, ranging from the surface to $0.01 \mathrm{hPa}$. The horizontal distribution of continental and marine aerosols, aerosols from desert dust and black carbon, are held constant at their respective default values. Concentrations of tropospheric sulphate aerosols and the atmospheric $\mathrm{CO}_{2}$ concentration and held fixed at preindustrial level, and a solar constant of $1,370 \mathrm{~W} \mathrm{~m}^{-2}$ is used.

The horizontal ocean grid in MICOM is almost regular with a grid spacing approximately $2.4^{\circ}$ latitude $\times 2.4^{\circ}$ longitude. To better resolve tropically confined dynamics, latitudinal grid spacing is gradually decreasing to $0.8^{\circ}$ near the Equator. The ocean model consists of 34 isopycnic layers below the non-isopycnic mixed layer. MICOM uses potential density with reference pressure at 2,000 decibar $(\mathrm{db})$ as vertical coordinate $\left(\sigma_{2}\right.$-coordinate), whereas the previous version of BCM (Furevik et al. 2003) used $0 \mathrm{db}$ $\left(\sigma_{0}\right.$-coordinate) as reference pressure. The potential density relative to $2,000 \mathrm{db}$ ranges from $\sigma_{2}=30.119 \mathrm{~kg} \mathrm{~m}^{-3}$ to $\sigma_{2}=37.800 \mathrm{~kg} \mathrm{~m}^{-3}$ in the isopycnic layers. The pressure gradient force is computed as the gradient of the geopotential on pressure surfaces and the geopotential is found by an accurate integration of the hydrostatic equation using in situ density.

\subsection{Mixed layer dynamics}

On top of the isopycnic layers there is a non-isopycnic mixed layer (ML), providing the connection between the atmosphere and the subsurface water. The density of the ML varies horizontally and temporally. Three mixing processes determine the mass exchange across the interface between the ML and the interior isopycnic layers. These are (1) diapycnal mixing, i.e. mixing across the density interfaces (2) the mass exchange caused by changes in mixed layer depth (MLD) determined by a Kraus-Turner type parameterization, and (3) convective adjustment (Kraus and Turner 1967; Gaspar 1988; Bleck et al. 1992). The diapycnal mixing is generally small compared to the other two processes, but in areas with dense plumes of water flowing down steep bottom slopes, the diapycnal mixing is considerable. To incorporate the shear instability and gravity current mixing a Richardson number dependent diffusivity is included (see Orre et al. 2009).

In contrast to earlier versions of this model, the MLD is no longer the best indicator of where deep convection occurs. If the ML becomes denser than the water in the layer below such that the water column tends to become unstable, convective mixing is parameterized to happen instantaneously to restore the stability. In previous versions of the model this was done by entrainment of the entire isopycnic layer below (Fig. 2a). This led to unphysical stepwise increase in MLD, and to spurious flows associated with the tilting of the density surfaces. In the updated version (Fig. 2b), stability is achieved without the large expansion of the ML. Here a slightly modified version of Bleck et al. (1992) has been used: A portion of water with density $\left(\rho_{k}\right)$ matching that of the receiving intermediate layer, $k$, is instead detrained from the ML, and replaced by an equal amount of water with a density just below that of the layer below. The expansion of layer $k$ is accounted for by an equal reduction in the thickness of layer $k-1$, giving a doming structure of the isopycnals.

\subsection{Methods}

The rate of which the water is detrained from the mixed layer due to instability is used as an indicator of where the convection in the model occurs, and where dense water is convected to increase the thickness of the intermediate layers.

In the model, more than $80 \%$ of the annual convection in the Nordic Seas (including Greenland, Iceland and Norwegian seas) and more than $90 \%$ of the annual convection in the Labrador Sea happens during the winter (herein November-April). This period has therefore been used when calculating convection rates and for calculating the atmospheric forcing variables used in the convection analysis in Sect. 3. For all other purposes annual values are used.

Since the focus of this paper is on multidecadal variability, the inter-annual variability has been removed using a centred third order Butterworth low-pass filter with a cut-off period of 5 years. In the correlation/regression analyses the time series have further been high-pass filtered using the same filter but removing time scales longer than 100 years. The latter is to avoid spurious statistical relationships due to model drift or other low-frequency changes. 
(a)

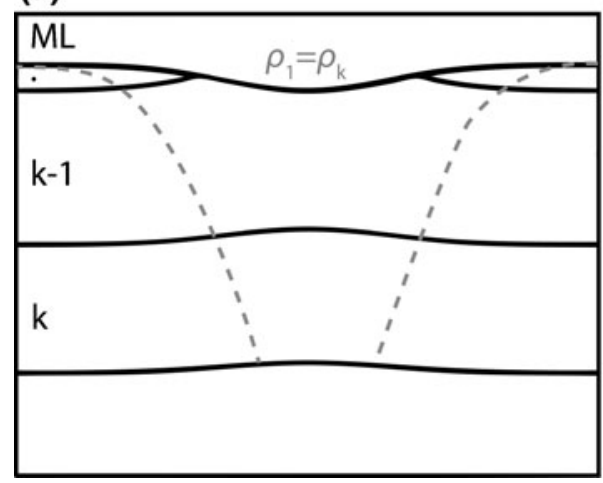

Fig. 2 A schematic of the isopycnals of the $\mathbf{a}$ old and $\mathbf{b}$ the new convection scheme in the model. Black lines show the isopycnals for an initial stable state and the gray dashed lines show the isopycnals after the adjustment for instability in the mixed layer. Letters in the

For significance testing a student $t$ test is used together with Chelton's (1983) method for estimating the effective number of degrees of freedom by taking into account the cross- and auto-covariance of the two time series. All correlations given in the text are significant above the $99 \%$ confidence level.

\section{Results}

\subsection{Atlantic meridional overturning circulation} (AMOC)

The Atlantic meridional overturning is quantified by the stream function

$\psi_{V}(y, z, t)=\int_{-z}^{0} \int_{0}^{L} v(x, y, z, t) d x d z$,

where the meridional velocity $v(x, y, z, t)$ is integrated from west $(x=0)$ to east $(x=L)$ across the basin, and from depth $z$ up to the surface.

Average AMOC in the BCM (Fig. 3a) shows an upper cell of northward flow from the surface and down to $800-1,300 \mathrm{~m}$ (where maximum $\psi_{V}$ is found). In the areas north of around $60^{\circ} \mathrm{N}$ the water sinks, and returns southward at depth as North Atlantic Deep Water (NADW). Below is a weak signal of the counter-circulating Antarctic Bottom Water $\left(1.2 \mathrm{~Sv} ; 1 \mathrm{~Sv}=10^{6} \mathrm{~m}^{3} \mathrm{~s}^{-1}\right)$, and the net inflow through the Bering Strait $(1.5 \mathrm{~Sv})$. By integrating the whole water column there will be a surplus of water flowing southward, which is equal to the amount of Bering Strait throughflow.

In this study the AMOC index is defined as the maximum overturning stream function value in the latitudinal (b)

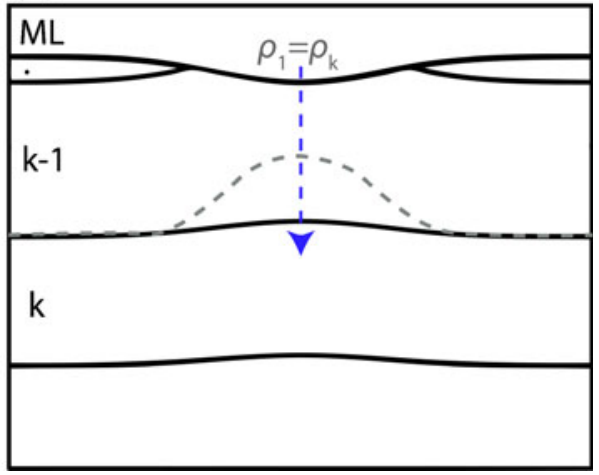

left side of the figures indicate layer number, where ML indicates the mixed layer. The density of the mixed layer $\left(\rho_{l}\right)$ equals the density $\left(\rho_{k}\right)$ of the intermediate layer $(k)$ before the convection

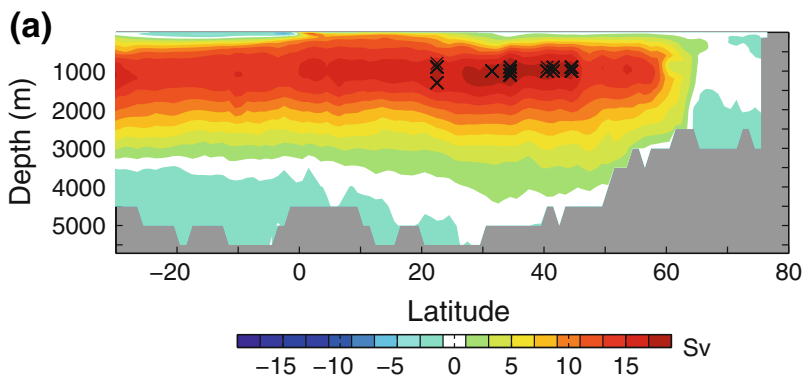

(b) 21
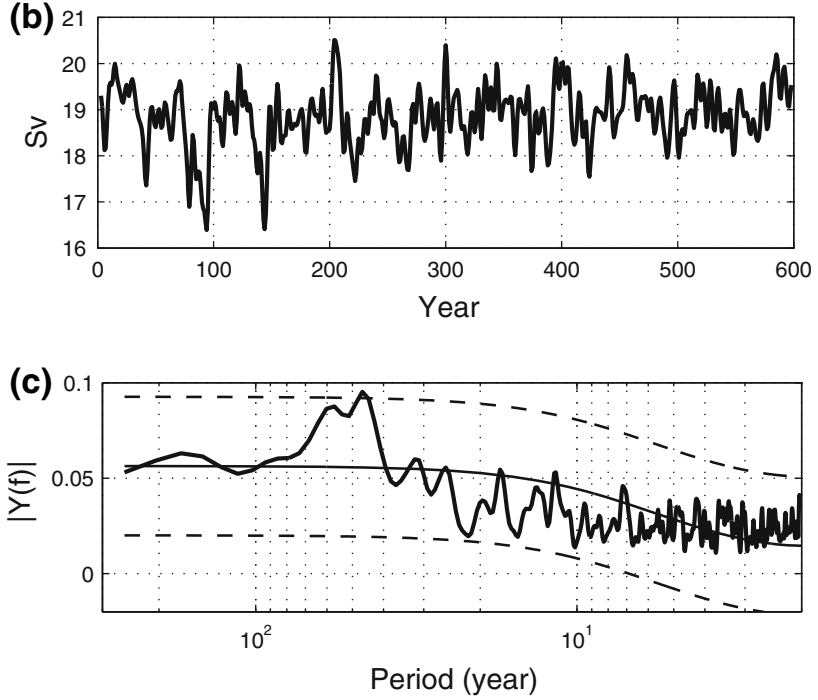

Fig. 3 a Mean state of the Atlantic meridional overturning stream function. Colour shading represents the zonally integrated volume transport, where positive (negative) values indicate a clockwise (anticlockwise) circulation. $\times$ marks the maximum overturning north of $20^{\circ} \mathrm{N}$ for the individual model years, giving the AMOC index. b The low-pass filtered annual mean AMOC index. Units given in $\mathrm{Sv}$ $\left(\mathrm{Sv}=10^{6} \mathrm{~m}^{3} \mathrm{~s}^{-1}\right)$. c Smoothed power spectrum of the linearly detrended annual data (thick line) together with the theoretical red noise spectrum (thin solid line) computed by fitting a first order autoregressive process with a $95 \%$ confidence interval (dashed lines) around the red noise 
band north of $20^{\circ} \mathrm{N}$ for each model year (Fig. 3b). The position of the maximum is found to vary between 22 and $45^{\circ} \mathrm{N}$. For decadal and longer time scales a latitudinal varying index has been shown to capture the basin-wide spinup/spin-down of the NADW cell, while the physical interpretation of this index on interannual time scales is shown to be potentially problematic (Vellinga and $\mathrm{Wu}$ 2004). The mean modelled AMOC index is $18.8 \mathrm{~Sv}$. From observational estimates the mean overturning circulation is in the range of 13-24.3 Sv, estimated from hydrographic observations at $24^{\circ} \mathrm{N}$ (Ganachaud and Wunsch 2000; Lumpkin and Speer 2003), $26.5^{\circ} \mathrm{N}$ (Cunningham et al. 2007), and $48^{\circ} \mathrm{N}$ (Ganachaud 2003), and from estimated NADW formation rates (Smethie and Fine 2001; Talley et al. 2003). In the model, the long-term mean at $26^{\circ} \mathrm{N}$ and $40^{\circ} \mathrm{N}$ are $17 \mathrm{~Sv}$ and $17.8 \mathrm{~Sv}$, respectively. Hence, the modelled overturning strength is well within the observational range.

There is little observational basis for constraining the longer term variability of the AMOC or the amplitude of fluctuations in general. The power spectrum of the modelled AMOC index shows power resembling a theoretical red noise spectrum. An exception is the increased power at periods around 40-70 years, where the energy at 45 years periodicity is found to be significant above the red noise (Fig. 3c). The time scales are similar to what is found in many other models (e.g., $\sim 50$ years in Delworth et al. 1993; 70-80 years in Jungclaus et al. 2005; 60 years in Zhu and Jungclaus 2008), and also similar to the 65-70 year variability in the North Atlantic surface climate suggested by observations (e.g., Schlesinger and Ramankutty 1994). Similar periods as for the maximum overturning north of $20 ; 70-80^{\circ} \mathrm{N}$ are also found when using maximum streamfunction fixed either at $26^{\circ} \mathrm{N}$ or $48^{\circ} \mathrm{N}$, or by using the first principal component of the streamfunction in the North Atlantic.

\subsection{Convective mixing regions}

The average modelled North Atlantic barotropic stream function (Fig. 4, contours) shows an anticyclonic circulation to the south (STG; subtropical gyre), and a cyclonic subpolar gyre (SPG) to the north. This circulation is a dominant feature of and represents an important part of AMOC, where the major surface currents make up the upper limb of AMOC.

A mixture of water from these two gyres is flowing across the Greenland-Scotland Ridge (GSR) into the Nordic Seas, where it circulates in a cyclonic direction, gradually releasing heat to the atmosphere, increases in density and sinks. In the model, the western part of the Nordic Seas cyclonic circulation cell is shifted east compared to observations (Fig. 4). This is most likely due to too zonal

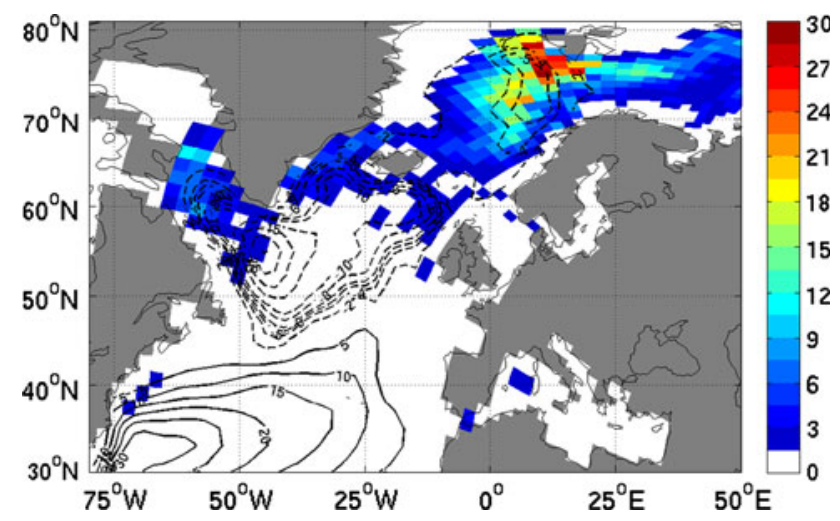

Fig. 4 North Atlantic long-term average winter (Nov-Apr) convection (colours; in $\mathrm{m}$ per day) together with long term average annual barotropic stream function (contours; in Sv). Solid lines indicate anticyclonic and dashed lines cyclonic circulation

westerlies bringing fewer storms into the Nordic Seas (Otterå et al. 2009), resulting in a large Nordic Seas sea ice cover in the model.

The strongest convection occurs over the continental slope southwest of Svalbard, with an average sinking rate of water from the mixed layer to the layers below reaching $30 \mathrm{~m} \mathrm{day}^{-1}$ in the winter months (Fig. 4, colour shading). Some open ocean convection also occurs in the eastern part of the Greenland Sea. Although the sinking rate may seem very large, horizontal advection rates responsible for exporting the denser water from the formation region are at least two orders of magnitudes larger. In the northwestern part of the Labrador Sea, the modelled sinking from plume convection reaches $12 \mathrm{~m} \mathrm{day}^{-1}$ while smaller values are seen in the Irminger Sea. The bulk part of this convection occurs on the continental shelves or on the shelf slopes.

In order to show the dominant pattern of variability in the convection, we have calculated the first Empirical Orthogonal Function (EOF1) of convection in the Nordic Seas (Fig. 5a), explaining $22 \%$ of the variance in the data. This shows a dipole pattern, indicating that when there is more convection in the northern Norwegian Sea (positive region on the map), there is less convection in the Fram Strait (negative region). One standard deviation increase in the principal component (PC1; Fig. 5b) corresponds to more than $5 \mathrm{~m} \mathrm{day}^{-1}$ change in sinking rates in the two regions. The convection follows the sea ice edge, where there is increased convection in the Norwegian Sea for more sea ice, and in the Greenland Sea for reduced sea ice extent. PC1 is dominated by decadal scale variability, in contrast to the longer time scales found for AMOC.

The corresponding leading EOF of the convection in the Labrador Sea (Fig. 5c) shows that most of the variability in the convection occurs in the northwestern part. In contrast to the Nordic Seas the mode shows a monopole structure. This pattern explains $19 \%$ of the variance in the convection 
(a)

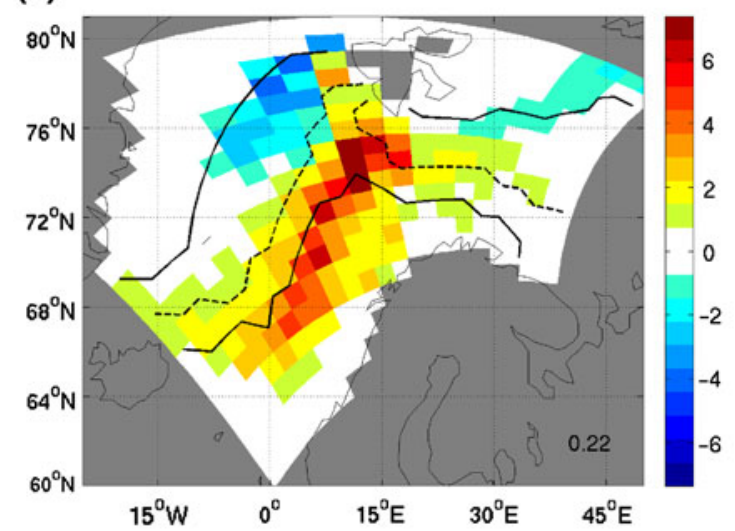

(b)

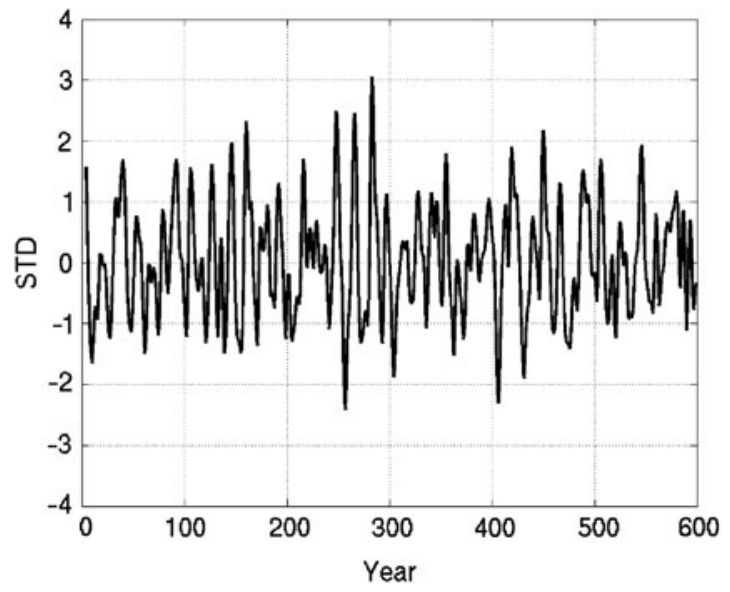

Fig. 5 The first EOF of the a Nordic Seas and c Labrador Sea convection (in $\mathrm{m}$ day ${ }^{-1} \mathrm{std}^{-1}$ ) calculated for the white and colored area. The convection time series for the individual grid points have been high-pass filtered with a cut-off period of 100 years. Black thick lines show the minimum, mean (dashed) and maximum March sea ice

time series. The corresponding PC1 for this pattern can be seen in Fig. 5d. The sea ice extent in the Labrador Sea does not reach the main convective region. Decadal scale variability similar to that of the Nordic Seas is also found for PC1 in the Labrador Sea.

The EOF for the full domain (including both the Nordic Seas and the Labrador Sea) is dominated by the variability in the Nordic Seas, due to the larger fluctuations in the Nordic Seas convection (Fig. 5a) compared to that for the Labrador Sea (Fig. 5c). The reason for the larger fluctuations in the Nordic Seas is that the density difference between the isopycnic layers is smaller for the higher densities, making it less energy consuming to detrain water from the mixed layer in the Nordic Seas.

In order to assess to what extent changes in AMOC are related to convective mixing, the winter convection in each grid cell is regressed onto the AMOC index (Fig. 6). The convection in the Labrador Sea is found to be related to a (c)

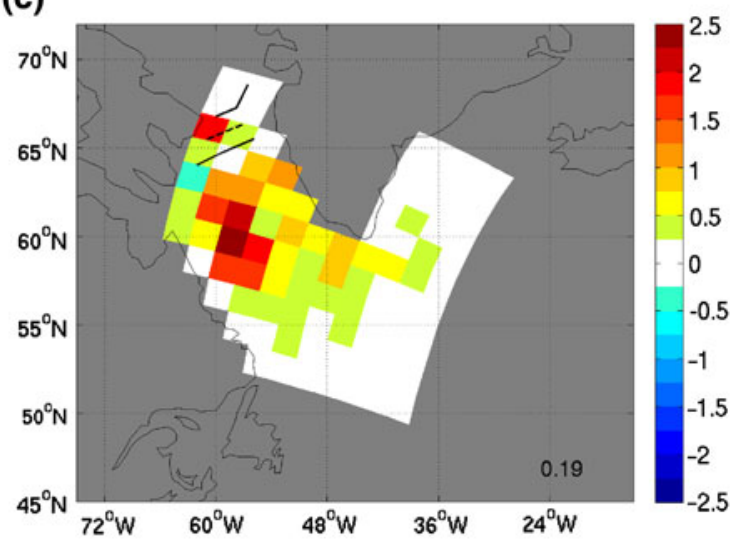

(d)

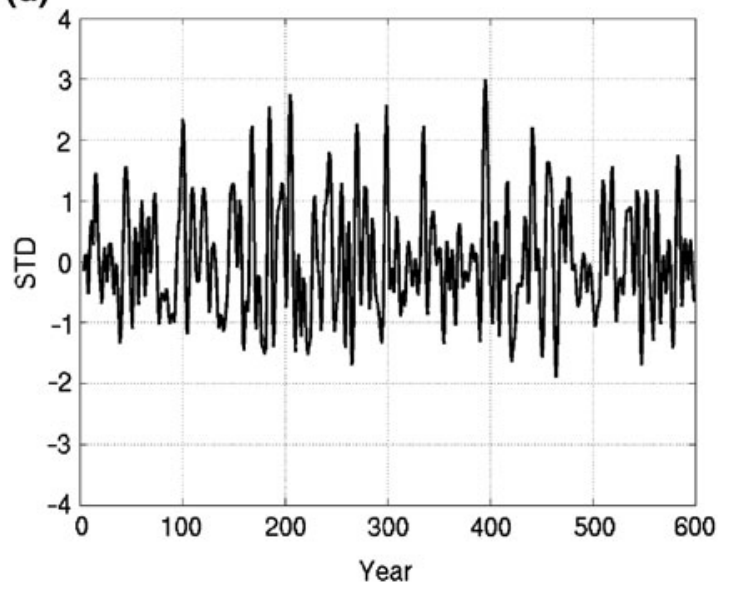

extent. The explained variance is given in the bottom right corner. The first principal components (in std) for the b Nordic Seas and d Labrador Sea have been low-pass filtered with a cut-off period of 5 years

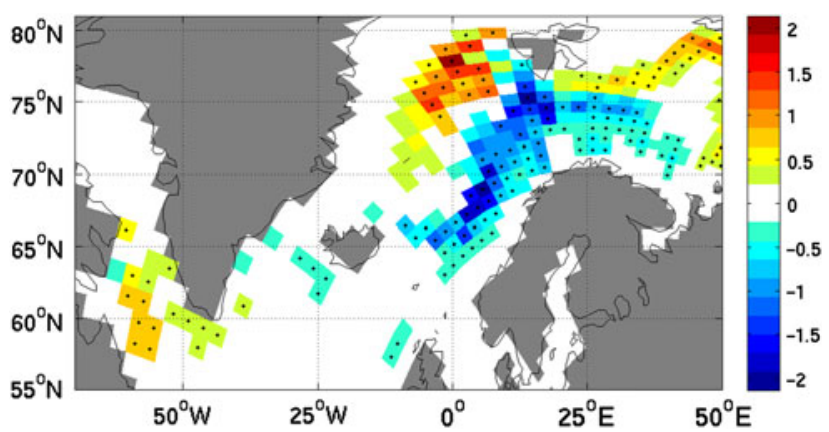

Fig. 6 Regression between winter convection and AMOC. Units are given in $\mathrm{m} \mathrm{day}^{-1} \mathrm{std}^{-1}$ of AMOC. Both time series are filtered using a band-pass filter with cut-off periods at 5 and 100 years. Dots indicate significance at $5 \%$ level

positive phase of AMOC. Correlating the convection (PC1 from Fig. 5d) with the AMOC index gives a maximum correlation of 0.5 where the convection is leading AMOC 
by two years. During the same AMOC phase, there is also an increased convection in the Greenland Sea, while there is a reduced convection in the Norwegian Sea. Correlating the Nordic Seas convection (PC1 from Fig. 5b) with the AMOC index gives a negative correlation of 0.3 at zero time lag.

\subsection{Atmospheric forcing: heat, freshwater and momentum fluxes in the Nordic Seas and Labrador Sea}

There is a net winter heat flux from the ocean to the atmosphere in the entire North Atlantic and Nordic Seas (Fig. 7a), with maximum heat loss found off Cape Hatteras, where the Gulf Stream leaves the eastern coast of North America, in the northeastern Nordic Seas, and in the Labrador Sea. The winter freshwater fluxes (Fig. 7b) are combined air-ocean (precipitation) and ice-ocean (sea ice melting/freezing) fluxes, and river runoff. The fluxes are generally large along the sea ice edge position (the border between positive and negative values), with a positive freshwater flux out of the ocean where sea ice is formed (the ocean becomes more saline), and a negative freshwater flux where sea ice melts. River runoff from land, and in the subtropics the net evaporation (E-P $>0$ ), also contributes to the freshwater flux. Note that the land contribution is relatively small since the data is from northern hemisphere winter with little river runoff. The momentum flux (Fig. 7c) is on average strongest in the North Atlantic Current region, around the Denmark Strait and in the Labrador Sea. A region of increased momentum flux is also seen south east of Svalbard.

In order to investigate where the buoyancy forcing (heat and freshwater fluxes) is increasing the local surface density and contributing to convection, and where the forcing has a stabilizing effect on the water column, regressions between the convection and each of the forcing terms have been calculated (Fig. 7d-f). Regions of positive (negative) regressions show where the forcing has a positive (negative) contribution to the convection. More heat loss, less freshwater input or more wind (i.e., more vertical mixing) generally acts to increase surface density and thus the convection. The results show that the strongest response in convection (i.e., detrainment rate) is due to changes in heat and freshwater fluxes. The freshwater flux is acting to reduce convection in the Fram Strait region, since it is negatively correlated with convection. The reason is that convection driven by more heat loss from more open water implies less sea ice freezing. Here the negative contribution from sea ice melt is counteracting the positive contribution from decreased precipitation. In contrast, in the Norwegian Sea a positive freshwater flux anomaly (more sea ice and evaporation and/or less precipitation) is contributing to convection. In the Labrador Sea all three contributions have a positive effect on the convection.

The convection in the Nordic Seas is significantly correlated with the NAO index $(R=-0.46)$, where NAO leads by 1 year. Averaged over the Nordic Seas for ice free areas, the negative NAO phase indicates less freshwater (due to less precipitation), more heat loss from the ocean to the atmosphere and slightly stronger wind. The correlations between the freshwater flux, and heat flux with the NAO index are -0.52 and -0.32 , respectively. The wind stress does not have a significant correlation with the NAO. The correlation between the convection and the heat and freshwater fluxes averaged over the Nordic Seas are close to 0.5 at zero time lag. The analysis further indicates stronger momentum fluxes and preconditioning of the mixed layer, where the momentum flux is found to lead convection by one year (Fig. 8a).

As similar to the Nordic Seas, the PC1 for convection in the Labrador Sea is found to have maximum correlation with all three atmospheric forcing parameters at zero lag (Fig. 8b). The strongest relation is between the convection and the heat flux, with a correlation of 0.51 , followed by the freshwater flux (0.45) and the momentum flux (0.41). The average Labrador Sea atmospheric fluxes (for ice free areas) all have a significant correlation with the positive phase of the NAO index, giving increased heat loss, less freshwater and stronger winds. The correlations between the NAO index and the fluxes are 0.69, 0.42 and 0.31, respectively at zero time lag.

\subsection{Volume transport across the Greenland-Scotland Ridge and Newfoundland section}

The water crossing the Greenland-Scotland Ridge (GSR) is usually classified into three different water masses (e.g., Hansen and Østerhus 2000; Eldevik et al. 2009); A warm and saline northward flow of Atlantic water (AW) with the Norwegian Atlantic Current (NwAC), a cold and fresh southward flow of polar water (PW) with the East Greenland Current (EGC), and cold and dense southward flow of deep water (DW) with the overflows (Overflowing Deep Water: ODW).

The PW is here defined as the net southward flowing water in the upper 16 density layers $\left(\sigma_{2}<36.9 \mathrm{~kg} \mathrm{~m}^{-3} \approx\right.$ $\sigma_{0}=27.6 \mathrm{~kg} \mathrm{~m}^{-3}$ ) with salinity less than or equal to $34.7 \mathrm{psu}$, and temperature less or equal to $8^{\circ} \mathrm{C}$. The net northward flow of AW is correspondingly defined as the rest of the water flowing across the GSR in the upper 16 density layers. The DW is the net southward flowing water beneath layer 16 , with an average density of $37.3 \mathrm{~kg} \mathrm{~m}^{-3}$ $\left(\sigma_{0} \sim 28.0 \mathrm{~kg} \mathrm{~m}^{-3}\right)$. The definitions of the water masses and corresponding currents are summarized in Table 1 with average water mass properties given in Table 2 . 
(a)

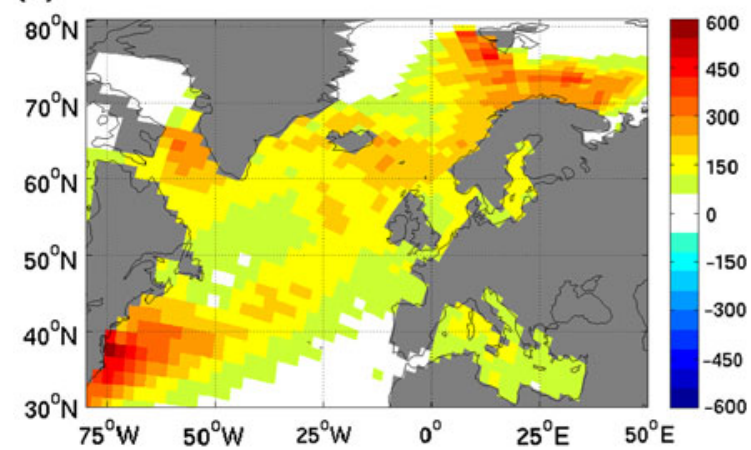

(b)

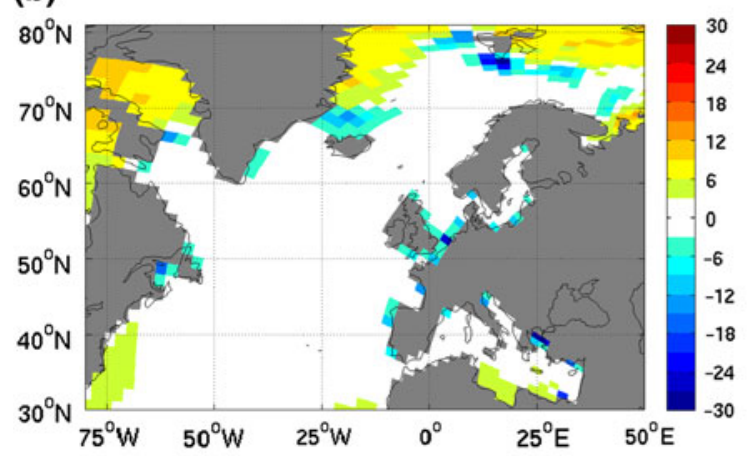

(c)

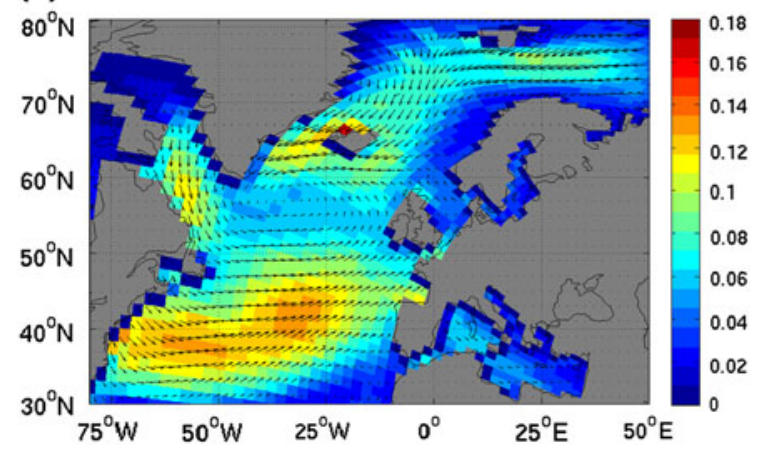

Fig. 7 Long term average winter (Nov-Apr) a heat flux $\left(\mathrm{W} \mathrm{m}^{-2}\right)$, where positive values indicate heat lost from the ocean, $\mathbf{b}$ freshwater flux $\left(\mathrm{mm} \mathrm{day}{ }^{-1}\right)$, where negative values indicate freshwater added to the ocean (as precipitation, river runoff or sea ice melt), and c momentum flux $\left(\mathrm{N} \mathrm{m}^{-2}\right)$, where colour shading shows the strength of the momentum flux and the arrows show the average wind

The location of the currents on the GSR can be seen in Fig. 9a. The Irminger Current is included in the definition of the NwAC and is situated to the east in the Denmark Strait. Time series for the volume transports in the various currents are shown in Fig. 9b. The modelled NwAC is on average 7.4 Sv, ECG 2.1 Sv and ODW 5.7 Sv. From observations, the corresponding values are $8.5 \mathrm{~Sv}$ (Østerhus et al. 2005), 0.7-3.0 Sv (Pickart et al. 2005, and references therein) and 6.4 Sv (Olsen et al. 2008), respectively. The modelled transports are in general in good agreement with the observation, and also the partitioning into $\sim 75$ and $25 \%$ between (d)

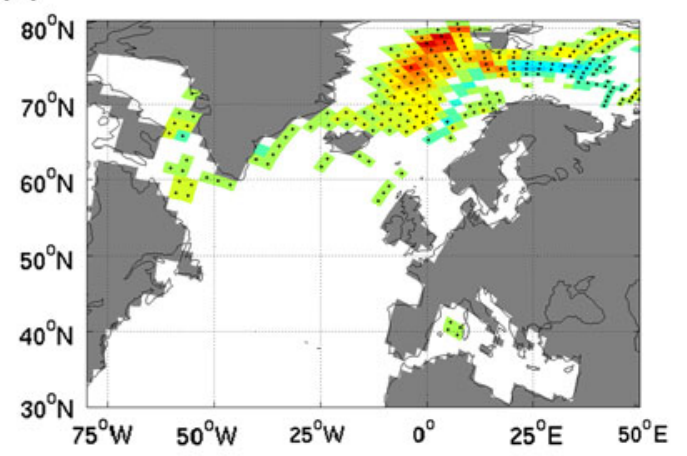

(e)

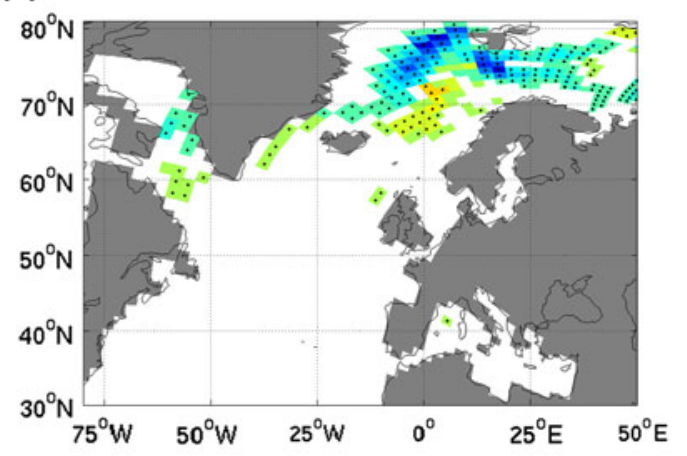

(f)

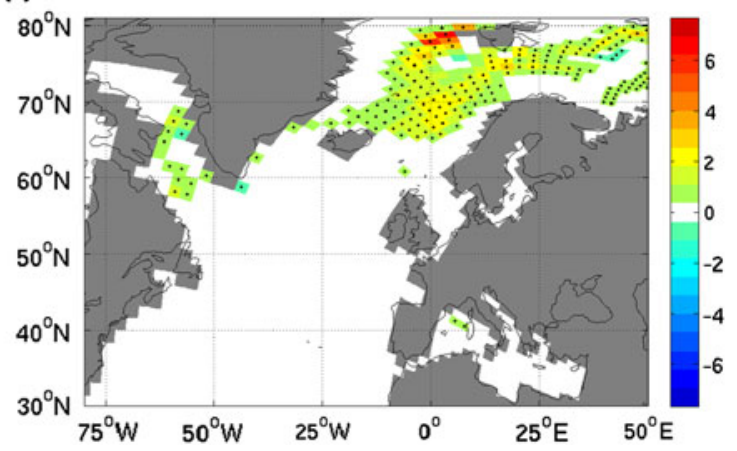

direction. Regression between the winter (Nov-Apr) convection and d heat flux, e freshwater flux and $\mathbf{f}$ momentum fluxes filtered with a band-pass filter. Units are given in $\mathrm{m}$ convection per standard deviation of forcing, and dotts mark significant correlations at $1 \%$ level using a two sided $t$ test and correction of degrees of freedom after the method of Chelton (1983)

ODW and EGC agrees fairly well to observations (Hansen and Østerhus 2000).

The ODW exits the Nordic Seas through two openings, the Faroe-Shetland Channel and the Denmark Strait, which on average contribute with 3.8 and $1.9 \mathrm{~Sv}$, respectively. The overflows in the two sections are anti-correlated, with a correlation coefficient of -0.47 . The variability of the ODW is mainly controlled by the Denmark Strait overflow, where the correlation between the two is 0.82 .

On average the total outflow of EGC and ODW, is larger than the inflow across GSR (0.4 Sv net southward 
Fig. 8 Cross correlation between the forcing time series of heat (hflx), freshwater (fwflx) and momentum fluxes averaged over the ice free areas within the black box indicated on the maps and the principal component (PC1) of the first EOF of the convection, for a the Nordic Seas and $\mathbf{b}$ the Labrador Sea. The time series have been filtered with a band-pass filter. Positive lags mean the forcing leads

\section{(a)}

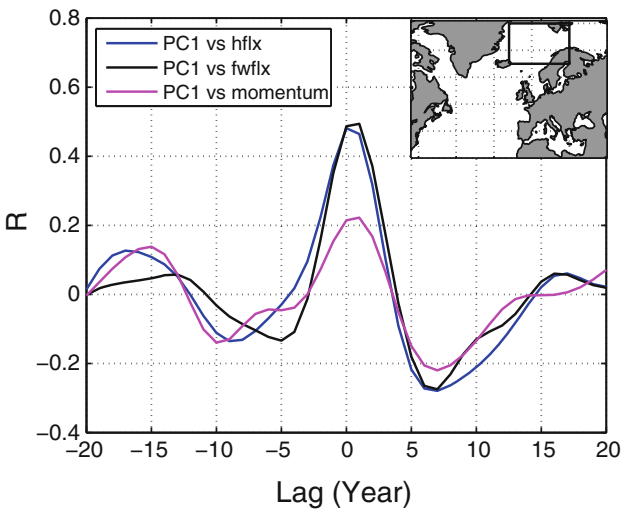

(b)

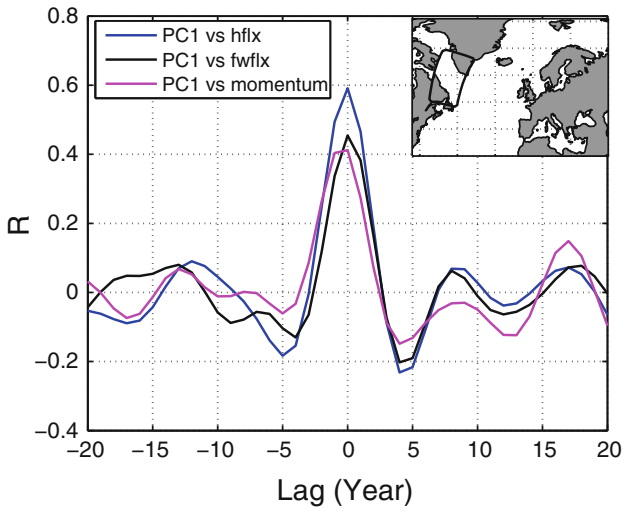

Table 1 Water mass definitions

\begin{tabular}{lllll}
\hline Water mass & Water mass flow & Current & $\sigma_{2}$-layer & $\mathrm{S}, \mathrm{T}$ \\
\hline AW & Norwegian Atlantic Current & NwAC & $1-16$ & $\mathrm{~S}>34.7 \mathrm{psu}$ or T $>8^{\circ} \mathrm{C}$ \\
PW & East Greenland Current & EGC & $1-16$ & $\mathrm{~S} \leq 34.7 \mathrm{psu} \& \mathrm{~T} \leq 8^{\circ} \mathrm{C}$ \\
DW & Overflowing Deep Water & ODW & $17-35$ & $\mathrm{~S}<35.3 \mathrm{psu}$ \\
LSW & Labrador Sea Water flow & LSWf & 17 & $\mathrm{~S}^{\mathrm{a}}<35.3 \mathrm{psu}$ \\
LNADW & Entrained Overflowing Deep Water & EODW & $18-35$ & \\
\hline
\end{tabular}

The water masses are defined using isopycnic layers $\left(\sigma_{2}\right)$, where some water masses also have additional salinity (S) and potential temperature (T) criteria. LSW and LNADW are taken from a section from Newfoundland to Portugal

a Salinity criteria only for layer 18

Table 2 Average water mass properties

\begin{tabular}{llclc}
\hline Water mass & $\mathrm{S}(\mathrm{psu})$ & $\mathrm{T}\left({ }^{\circ} \mathrm{C}\right)$ & $\sigma_{2}\left(\mathrm{~kg} \mathrm{~m}^{-3}\right)$ & $\mathrm{Flow}(\mathrm{Sv})$ \\
\hline AW & 35.70 & 10.5 & 36.3 & -7.4 \\
PW & 34.25 & 3.3 & 36.4 & 2.1 \\
DW & 35.04 & 1.4 & 37.3 & 5.7 \\
LSW & 35.22 & 4.7 & 36.9 & 4.9 \\
LNADW $^{\mathrm{a}}$ & 35.29 & 4.0 & 37.1 & 8.7 \\
\hline
\end{tabular}

Positive volume transports on the GSR indicate net southward transport. The LSW and LNADW flow is only representing the southward transport within the criteria given in Table 1. The hydrography is averaged for water in the net flow direction

Salinity (S), temperature (T), density $\left(\sigma_{2}\right)$ and volume transports (flow) for the whole period

${ }^{\text {a }}$ Large difference in properties across the Mid-Atlantic Ridge (see Langehaug et al. 2011)

transport). This is essentially balanced by the inflow to the Nordic Seas through the Fram Strait $(1.1 \mathrm{~Sv})$ and the British Channel $(0.5 \mathrm{~Sv})$, and the outflow through the Barents Sea opening (1.3 Sv; Table 3). The seeming $0.1 \mathrm{~Sv}$ imbalance of the net budget is due to round-off errors when relating the exchanges at GSR to water masses.

The described exchange of the three water masses across the GSR essentially carries the advective convergence of ocean heat in the Nordic Seas and Arctic Ocean. This net poleward heat transport (PHT) is generally understood to scale with the strength of AMOC (Gregory et al. 2005; Kuhlbrodt et al. 2007) and in this model PHT appears as a constraint on AMOC as PHT variability leads AMOC variability by 3 years. Furthermore, as PHT is the net heat given up by the ocean to the atmosphere, it is the overall thermal constraint on northern water mass transformation. Deep convective mixing is a part of this transformation and it thus appears as a lagged response to PHT (but not a controlling factor for AMOC in this model).

The water masses south of the GSR have been studied in a section spanning the entire North Atlantic, from Newfoundland $\left(\sim 48^{\circ} \mathrm{N}\right)$ in the west to Portugal $\left(\sim 38^{\circ} \mathrm{N}\right)$ in the east, hereafter called the Newfoundland section (Fig. 10a). The Labrador Sea Water (LSW) in this section is defined as the water in layer $17\left(\sigma_{2}=36.9 \mathrm{~kg} \mathrm{~m}^{-3}, \sigma_{0} \sim 27.9 \mathrm{~kg} \mathrm{~m}^{-3}\right)$ with salinity less than 35.3 psu (Langehaug et al. 2011), 
Fig. 9 a Cross section of the Greenland-Scotland Ridge, where the salinity is shown in colours. The black line shows the salinity criteria dividing the southward flowing East Greenland Current (EGC) from the northward flowing Irminger Current (IC), which is included in the definition of the Norwegian Atlantic Current (NwAC). White line is the density line dividing the upper flow from the deep overflows (ODW). b Low-pass filtered annual volume transports (in $\mathrm{Sv})$ across the ridge. Positive net flow indicates southward flow, where the northward flowing NwAC is weaker than the sum of the southward flowing (EGC and ODW)

Table 3 Long-term annual mean transports in and out of the Nordic Seas calculated relative to a reference salinity of 34.9 psu and a reference temperature of $0^{\circ} \mathrm{C}$

* Only advective transports

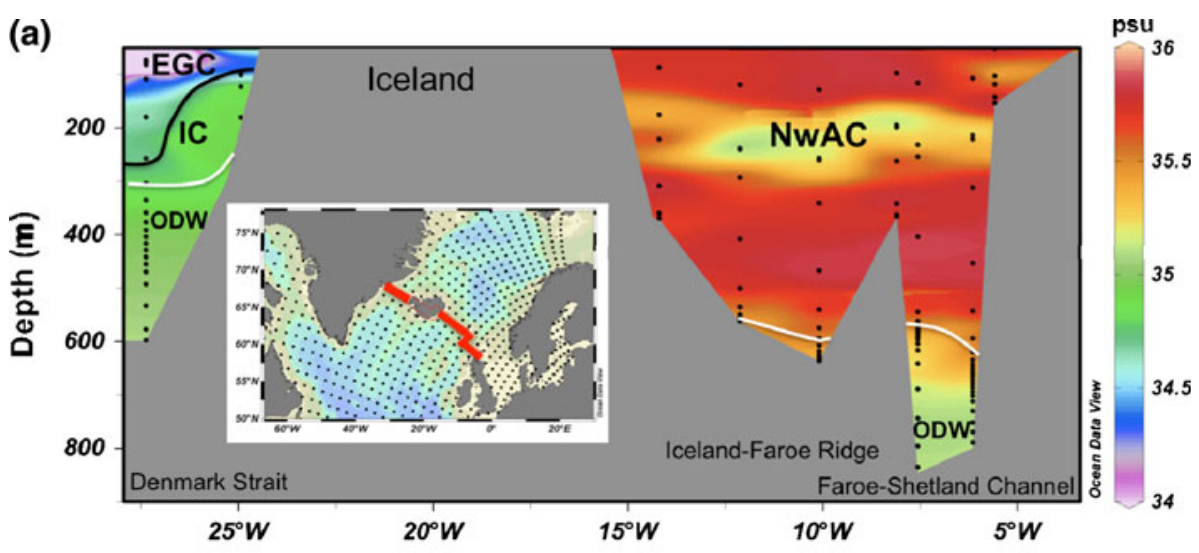

(b)

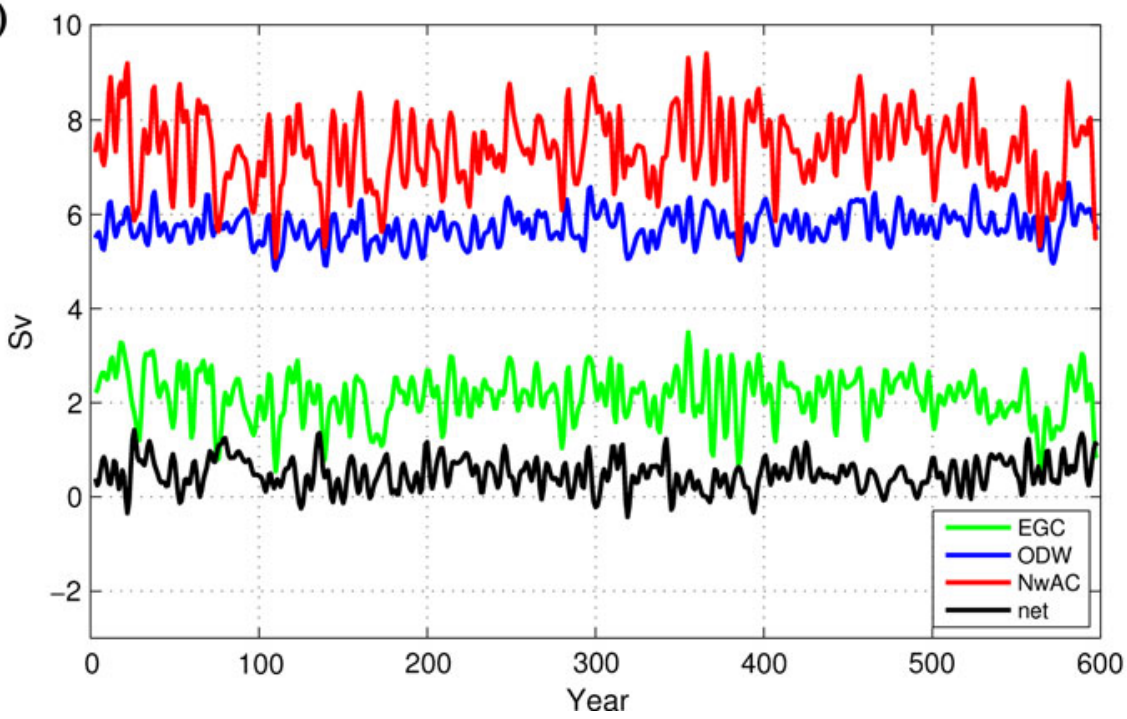

\begin{tabular}{lcccc}
\hline Section & Volume $(\mathrm{Sv})$ & Salt $\left(\mathrm{kt} \mathrm{s}^{-1}\right)$ & Heat $(\mathrm{TW})$ & Freshwater $(\mathrm{mSv})$ \\
\hline British Channel & 0.5 & 18.7 & 28 & -11 \\
Fram Strait & 1.1 & 37.8 & -14 & 60 \\
Barents Sea opening & -1.3 & -48.5 & -61 & 42 \\
Denmark Strait & -3.2 & -112.1 & -6 & -32 \\
Iceland-Faroe & 2.2 & 79.5 & 96 & -59 \\
Faroe-Scotland & 0.7 & 26.9 & 127 & -67 \\
Nordic Seas & & & & \\
Net (In-Out) & 0.0 & 2.3 & 170 & -67 \\
External & & -2.3 & -170 & 66 \\
Storage anomaly & & 0.0 & 0 & 0 \\
GSR transports* & & & 307 & -365 \\
NwAC & 7.4 & 269.9 & -23 & 13 \\
EGC & -2.1 & -74.8 & -27 & 185 \\
ODW & -5.7 & -206.4 & &
\end{tabular}

forming the upper part of the Deep Western Boundary Current at the exit of the Labrador Sea. In the deep basins on either side of the mid-Atlantic ridge (layer 19-35), we have the Lower North Atlantic Deep Water (LNADW).
The upper layer of LNADW (layer 18) in the western Atlantic basin has the same salinity criteria as the LSW. This is due to the presence of higher salinity Mediterranean water on the eastern side of the mid-Atlantic ridge 
(Langehaug et al. 2011), which we do not want to include in the deep water from the northern source region. A summary of the definitions of the water masses is given in Table 1 .

As the ODW cascades down the steep slope of the GSR it mixes with the ambient warm and saline Atlantic water, increases in volume and decreases in density. Figure 11 shows which density layer that is situated at the bottom, which gives an indication of where strong diapycnal mixing occurs in the model. Areas with large changes in density across sloping topography, such as at the GSR, are associated with substantial entrainment. This involves the surrounding Atlantic water being mixed into the ODW as it descends down the steep slopes of the GSR. The main areas of entrainment into the ODW are downstream of the Denmark Strait and the Faroe-Shetland Channel, where the layer situated at the bottom changes rapidly downstream. The same areas of entrainment are also found in Dickson and Brown (1994) and Xu et al. (2010). The decrease in density of the DW as a consequence of the entrainment south of the ridge can be seen in Fig. 12 (transition from filled to open blue circles). The cold and dense ODW becomes both more saline and warmer as it is transported toward the Newfoundland section.

The increased volume transport associated with Nordic Seas deep water can be seen in the Newfoundland section (Fig. 10a) as Entrained Overflowing Deep Water (EODW) around two years later (not shown). The water entrained into the ODW downstream of the GSR is defined as the difference between the EODW (8.7 Sv) and the ODW $(5.7 \mathrm{~Sv}) 2$ years earlier, where the two years give the time from a signal is found on the ridge until the same signal is found in the Newfoundland section. This gives an average entrainment of $3 \mathrm{~Sv}$. Dickson and Brown (1994) estimated that the dense overflows double in volume transports due to entrainment, which is somewhat more efficient than found in this model. Observational estimates of EODW (8.9 Sv; Schott et al. 2004) are similar to the modelled values.

In addition to the contribution from the Nordic Seas, the convection in the Labrador Sea contributes on average 4.9 Sv to the NADW, similar to observational estimates of 4.5 Sv (Yashayaev 2007). The time series for the volume
Fig. 10 a Average salinity in the Newfoundland cross section (colours) and the location of the Labrador Sea Water (LSW; gray line) together with the upper limit of the Entrained Overflowing Deep Water (EODW; thick white line). The thin white line marks the salinity criteria for LSW and EODW.

b The northward volume transport aloft (Atlantic Meridional Overturning Circulation-AMOC) together with the southward volume transports of EODW and LSW derived from the section shown in a. The sum of EODW and LSW (gray line) together makes up the lower limb of the AMOC. Transports are given as absolute values

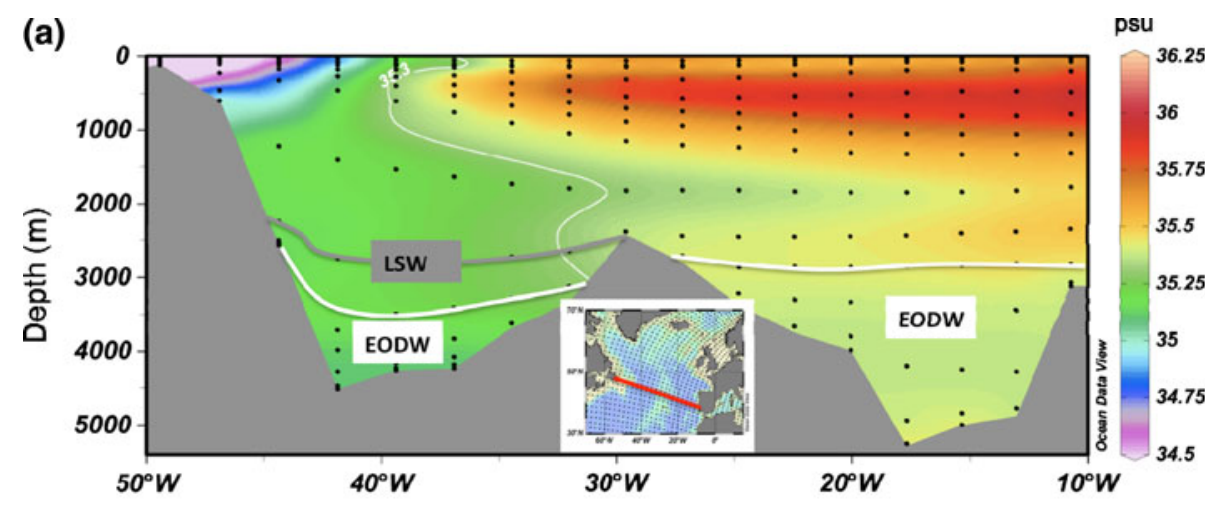

(b)

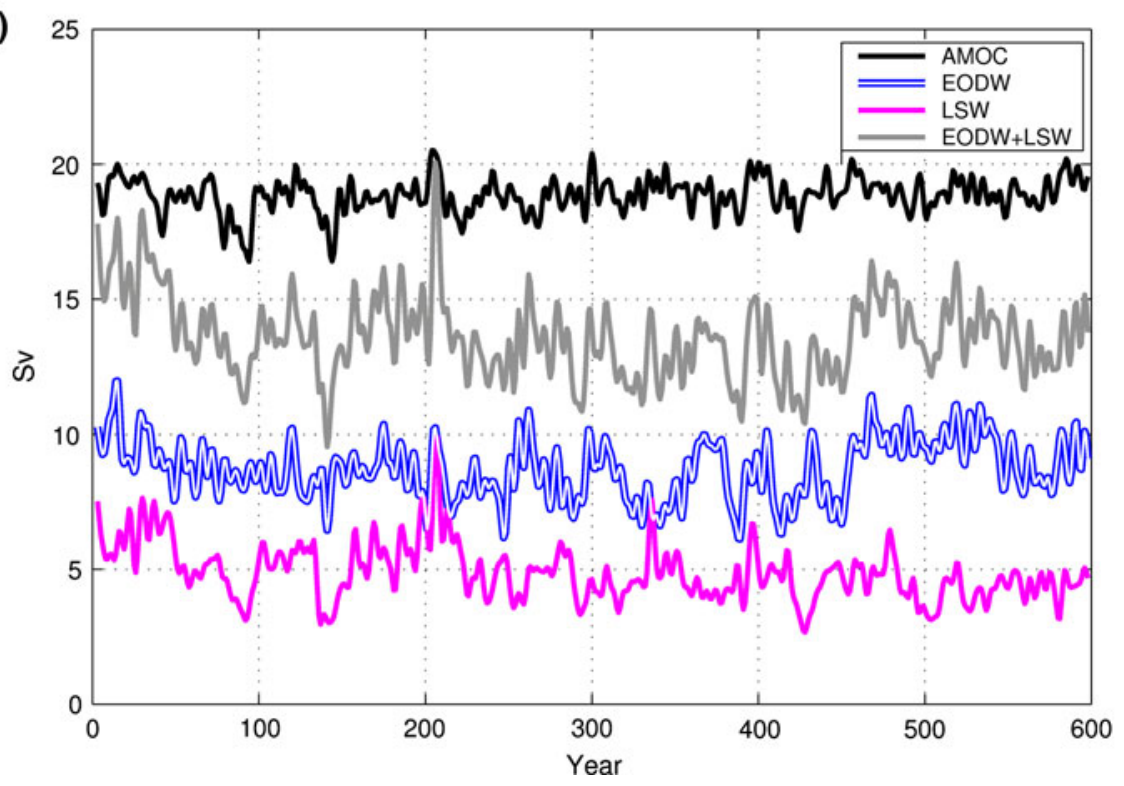




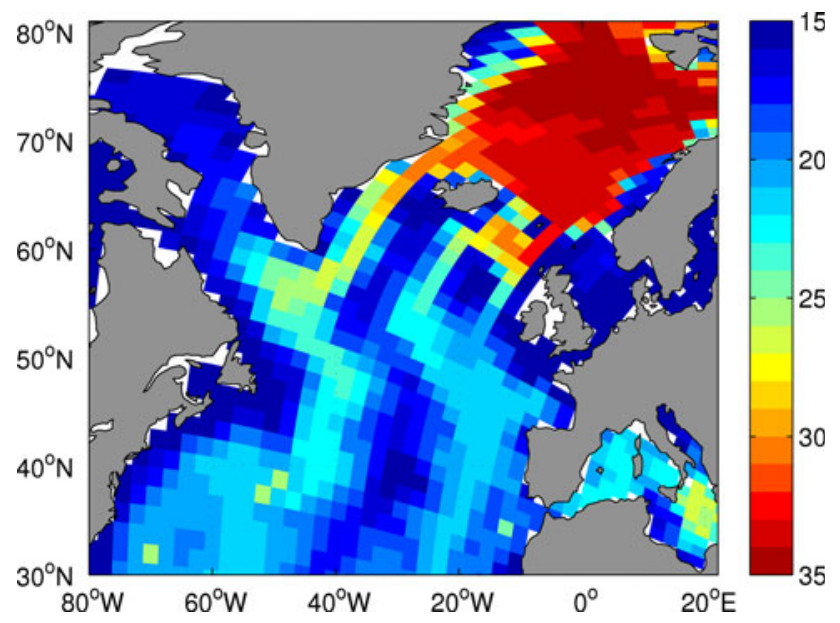

Fig. 11 Isopycnic layer situated at the bottom of each grid cell, which points to where strong diapycnal mixing occurs. Only layers with a thickness exceeding $0.5 \mathrm{~m}$ are included. Colours show layer number

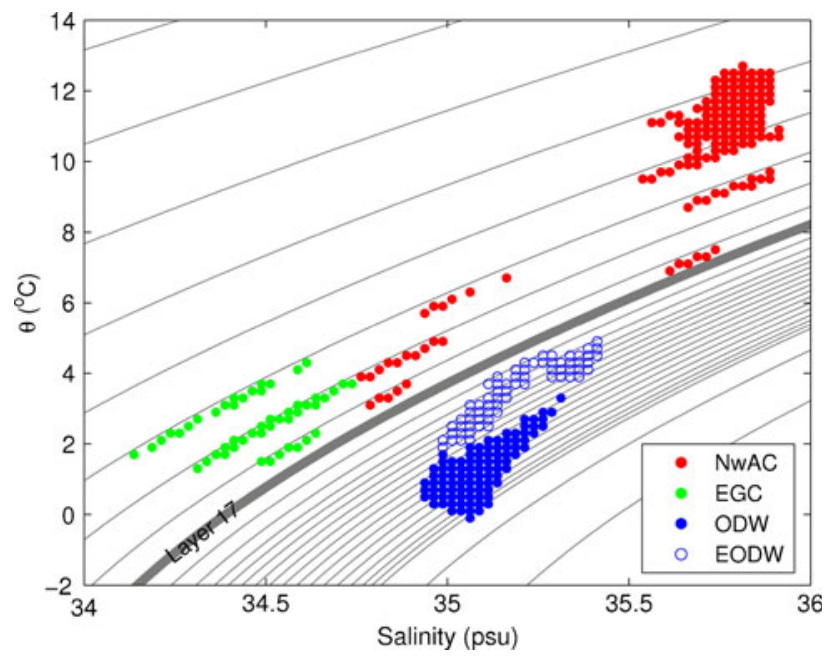

Fig. $12 T S$-diagram for the net flow crossing the Greenland-Scotland Ridge (dots): Norwegian Atlantic Current (NwAC), East Greenland Current (EGC), Overflowing Deep Water (ODW), and the entrainment of water south of the ridge resulting in the southward flow of Entrained Overflowing Deep Water (EODW) through the Newfoundland section (open circles). Dots are shown for each TS-bin with volume transports larger than $0.01 \mathrm{~Sv}$ for each $T S$-bin

transports in the Newfoundland section are shown in Fig. 10b. There is quite large variability of both the LSW flow and the EODW. The variability of the EODW is mainly due to the entrainment since the ODW is relatively constant in comparison (see Fig. 9b). On average the flow of NADW (EODW + LSW: gray line; $13.6 \mathrm{~Sv}$ ) is $5.2 \mathrm{~Sv}$ lower than the AMOC $(18.8 \mathrm{~Sv})$. If we also include the Mediterranean water, the sum is $17.5 \mathrm{~Sv}$. Additional dense water is found in layer 16 . This water can not be attributed to any specific source region since it also consists of re-circulated water, hence is omitted from the further analysis. The AMOC co-vary with the flow of NADW $(R=0.45)$, where the LSW flow dominates the variability of NADW $(R=0.68)$, for NADW leading by 1 year.

\section{Discussion}

In the previous section we described the water masses and circulation in the North Atlantic. The main regions of deep convection are found in the Nordic Seas and in the Labrador Sea. The convection in the Labrador Sea has a direct connection with the deep North Atlantic circulation, while the links between the Nordic Seas convection and exchanges across the ridge are more complicated due to the barrier of the GSR. The deep water formed in these two regions make up the bulk part of the North Atlantic Deep Water constituting the lower limb of the AMOC.

Admittedly, course resolution general circulation models may have some generic weaknesses by not being able to resolve the smaller scale features of the circulation, e.g., energetic fronts and ocean eddies. Recent findings indicate that synoptic surface winds and small scale ocean eddies have much more important roles in the circulation than what has been the traditional view, and that the various components of the overturning circulation are varying both spatially and temporally in contrast to what has been the perception from studies of ocean tracers or from coarse resolution climate models (see Lozier 2010, and references therein).

\subsection{Water mass transformation in the Nordic Seas}

In the Bergen Climate Model convection occurs both in the Nordic Seas and in the Labrador/Irminger seas in contrast to many earlier model studies showing deep convection mainly in the Labrador Sea (e.g., Deshayes et al. 2007; Zhu and Jungclaus 2008). For models that have deep convection in the Nordic Seas, convection is mainly associated with the central Greenland Sea (Bentsen et al. 2004; Dong and Sutton 2005; Jungclaus et al. 2005). The convection in this version of the Bergen Climate Model occurs more towards the eastern rim of the Nordic Seas. This is consistent with the concept first introduced by Mauritzen (1996), where the inflowing Atlantic Water gradually looses buoyancy and sinks as it circulates around the basin. This is due to heat loss (while freshwater forcing partly compensates), as has been shown in several other observational studies (Rudels et al. 1999; Segtnan et al. 2011).

To elucidate the water mass transformation in the Nordic Seas, volume, heat and freshwater budgets, including both the model advection and eddy diffusion of tracers, are calculated for the region (Table 3). The volume transport budget for the Nordic Seas is closed, with estimated 
transports close to observations (cf., Østerhus et al. 2005; Skagseth et al. 2008). In the following, all heat transports/ fluxes are given relative to $0^{\circ} \mathrm{C}$. Vertical heat fluxes of $170 \mathrm{TW}\left(1 \mathrm{TW}=10^{12} \mathrm{~W}\right)$ is lost to the atmosphere within the Nordic Seas. This is in good agreement with recent estimates of $197 \mathrm{TW}$ (Segtnan et al. 2011). A modest storage anomaly term of $-0.05 \mathrm{TW}$ is calculated from the total temperature drift of $-0.19^{\circ} \mathrm{C}$ over the entire 600-year period.

Looking at the freshwater budget, all transports are calculated relative to a salinity of $34.9 \mathrm{psu}$. Based on the vertical fluxes, the net freshwater input from evaporation minus precipitation (E-P), runoff and sea ice melting/ freezing is $66 \mathrm{mSv}\left(1 \mathrm{mSv}=10^{3} \mathrm{~m}^{3} \mathrm{~s}^{-1}\right)$, which is equivalent to removing salt at a rate of $2.3 \mathrm{kt} \mathrm{s}^{-1}\left(1 \mathrm{kt} \mathrm{s}^{-1}\right.$ $=10^{6} \mathrm{~kg} \mathrm{~s}^{-1}$ ). The seeming imbalance of $1 \mathrm{mSv}$ in the freshwater budget between ocean transports and the vertical fluxes is due to round-off errors. The external freshwater forcing does not add any volume to the budget, but is rather a "virtual salt flux" accounted for by adjusting the salinity according to the forcing. The external freshwater input in the model compares favourably with recent observational-based estimates of around $55 \mathrm{mSv}$ (Dickson et al. 2007; Segtnan et al. 2011). Note that the model includes river runoff to the Baltic Sea and the North Sea, which is not included for in observational-based estimates. The change in storage is $0.02 \mathrm{kt} \mathrm{s}^{-1}(0.03 \mathrm{mSv}$ of freshwater), calculated from the total salinity increase of 0.06 psu over the entire 600-year period.

From the freshwater and heat budgets, there is an increase in the Nordic Seas density of around $0.07 \mathrm{~kg} \mathrm{~m}^{-3}$ over the entire period, which is partly due a net heat loss and partly due to a net freshwater export from the Nordic Seas resulting in colder and more saline water. In the model, it is not found that a density difference of this magnitude in the Nordic Seas has any significant consequence for the dynamics. Furthermore, the change in density is not affecting the intensity of the overflow as one should expect (e.g., Curry and Mauritzen 2005). In the model there is a decrease in the steric sea surface height in the Nordic Seas compensating for the change in density (not shown). A similar mechanism has been discussed by Olsen et al. (2008).

Based only on the advective heat and freshwater budgets, the water mass transformation from the warm and saline inflowing AW to the two distinct outflowing water masses, PW and DW can be described. Most of the heat transported across GSR by the NwAC (307 TW, Table 3) is lost to the atmosphere (170 TW) within the Nordic Seas. This can be seen from Fig. 12, where the AW with a temperature of on average $10.5^{\circ} \mathrm{C}$ (Table 2) transforms into DW and PW with temperatures of 1.4 and $3.3^{\circ} \mathrm{C}$, respectively. The modelled heat transported into the Nordic Seas crossing the GSR compares well with the observational estimates of 313 TW from Østerhus et al. (2005). The EGC and ODW remove 23 and $27 \mathrm{TW}$ of heat from the Nordic Seas. The southward positive heat transport of the EGC is not seen in observations, as observed temperatures are lower than in the model, where the $\mathrm{PW}$ is $-1.5^{\circ} \mathrm{C}$ and $\mathrm{DW}$ $0.5^{\circ} \mathrm{C}$ (Rudels et al. 1999; Eldevik et al. 2009).

The circulation in the Nordic Seas can be divided into a horizontal estuarine and a vertical overturning part. To a good approximation, there is a volume balance on GSR both in observations (Hansen et al. 2008) and in the model. Hence there is a strong and significant correlation between the strength of the inflow and outflows at zero lag. The correlation coefficients between the NwAC and the EGC, and the ODW are 0.86 and 0.65 , respectively. The weaker correlation between the ODW and EGC (0.44) indicates that the volume transports of the two water masses are depending on two factors: firstly, increased inflow will tend to increase transports in both (positive correlation); whilst, secondly, increased heat loss will tend to increase ODW and decrease EGC transports (negative correlation). Indeed, correlation between the EGC and ODW volume transports when the variability of the NwAC is removed through linear regression gives a significant negative correlation of -0.33 . The increase in EGC relative to ODW occurs for negative anomalies in the Nordic Seas density as should be expected (not shown).

\subsection{Mechanisms controlling AMOC variability}

on decadal to multidecadal scale

Labrador Sea convection is forced by heat loss and, to a slightly lesser degree, a negative freshwater flux (mainly due to less precipitation) associated with a positive phase of the North Atlantic Oscillation $\left(\mathrm{NAO}^{+}\right)$at zero time lag (Fig. 8b). During $\mathrm{NAO}^{+}$northerly air masses blow over the Labrador area, where it is found to be colder and dryer than normal (Hurrell 1995), giving favourable conditions for deep convective mixing. In addition, an increased Labrador Sea sea-ice extent is also found at this time, contributing additionally to the convection through brine release.

The convection in the Labrador Sea is found to be related to a positive phase of AMOC (Fig. 6). As similar to the Labrador Sea, the heat and freshwater fluxes, forced by the NAO, contributes to the variability in the Nordic Seas convection. Here the increased air-sea fluxes are connected to a negative phase of $\mathrm{NAO}$, when fewer storms are bringing warm and moist air masses into the Nordic Seas (Hurrell 1995; Furevik and Nilsen 2005).

So far the results are in agreement with the traditional view that NAO is responsible for the deep water formation, and hence AMOC (e.g., Dickson et al. 1996; Curry et al. 1998; Häkkinen 1999; Eden and Willebrand 2001; Bentsen 
et al. 2004; Deshayes and Frankignoul 2008), where in this model there is a correlation of 0.4 between NAO and AMOC. However, there is one important difference in this study: For the Nordic Seas the convection does not determine the water mass exchange across the GRS but is rather a result of it. An increased water mass exchange leads to an increased net poleward heat transport (PHT); the total heat available for northern water mass transformation.

An increased water mass exchange across the GSR is associated with an atmospheric sea level pressure (SLP) pattern (Fig. 13a) very similar to the negative phase of the so-called Scandinavia pattern (Bueh and Nakamura 2007; EOF3 of model SLP in the Atlantic sector explaining 12\% of the variability; Fig. 13b), also called the Eurasian type 1 pattern (Barnston and Livezey 1987). This pattern is dominated by a deep low-pressure anomaly located over Scandinavia and a weaker high-pressure anomaly over Greenland. This atmospheric pattern is associated with stronger than normal northerly winds blowing over the Nordic Seas. The wind has both a direct and an indirect effect on the water mass exchange, where: (1) The winds set up an increased Ekman transport towards Greenland and the sea ice edge, leading to an elevated sea surface height in the west and reduced in the east, where the alongridge gradient gives rise to an increased geostrophic flow across the ridge (Olsen et al. 2008). (2) There is a rapid barotropic adjustment to the surface elevation gradient induced by the Ekman transport (e.g., Nilsen et al. 2003) giving an increased barotropic circulation. Due to volume conservation a strengthening of the Norwegian Atlantic Current and increased PHT will be the consequence. These results also support the findings of Hansen et al. (2010), where they state that the Iceland-Faroe inflow to the Nordic Seas is driven by a pressure gradient due to low sea level in the southern Norwegian Seas.

The PHT is a measure of the water mass transformation actually taking place within the Nordic Seas, contributing to the ODW across the GSR. It has a correlation with AMOC of 0.42 , where PHT is leading AMOC by 3 years. Thus, the deep convective mixing is not necessarily an ideal measure of the total water mass transformation that is taking place in the Nordic Seas (Fig. 4), since some of the deep convection occurring will end up below the sill depth of the GSR, and therefore not contribute directly to the ODW.

Increased heat transport into the Nordic Seas will lead to more sea ice melting, with the increased PHT leading reduced sea ice cover by 4 years. As the sea ice retreats, more water mass transformation will occur through open ocean convection in the central Greenland Sea, concurrent with a decrease in the Norwegian Sea convection, and a decreased total Nordic Seas convection (from Figs. 4, 5a). Furthermore, from Fig. 6 the in-phase relation of the timing of high AMOC and an increased convection in the central Greenland Sea is seen, while there is a reduced convection in the Norwegian Sea. A schematic of the mechanisms leading to an increase in the deep water masses supplying AMOC is given in Fig. 14. Labrador Sea convection has a direct influence on AMOC variability, while the water mass transformation in the Nordic Seas is rather a result of PHT, where increased PHT is both associated with increased water mass exchange on the GSR, and a stronger AMOC.

The two convective regions' influence on AMOC can be further understood through their interaction via the Subpolar Gyre (SPG). In an accompanying paper by Langehaug et al. (2011) a more detailed assessment of North Atlantic/Arctic exchanges including the influence on, and their interaction within the SPG can be found.

\section{Summary and conclusions}

An increased understanding of the atmospheric and oceanic climate variability is needed for prediction of future climate, where the response to altered air-sea fluxes might play an important role in the Atlantic oceanic heat transport. In this study we have investigated the mechanism for decadal to multidecadal Atlantic Meridional Overturning Circulation (AMOC) variability in a multi-century, preindustrial control simulation, using the Bergen Climate Model.

The modelled AMOC is found to be within the observed range of Atlantic overturning, and has increased energy in a 40-70 year frequency band. A novelty with this study is that convective mixing is directly diagnosed in the model, opposed to most previous model studies. Deep-water formation is found both in the Labrador Sea and in the Nordic Seas, but the linkages to the AMOC differ substantially.

The water mass exchange, and hence poleward heat transport (PHT) on the Greenland-Scotland Ridge (GSR) is driven by increased northerly winds associated with the Scandinavian Pattern, the third mode of the sea level pressure in the Atlantic sector. The PHT sets the mode of variability of the convection in the Nordic Seas through the sea ice extent. For high PHT the sea ice edge retracts, resulting in more open ocean convection in the Greenland Sea and less in the Norwegian basin. On average most of the Nordic Seas convection occurs in the Norwegian basin, and a reduction in the Norwegian basin convection is concurrent with an overall decrease in the total Nordic Seas deep-water formation.

Air-sea fluxes, related to opposite phases of the North Atlantic Oscillation (NAO), are contributing to the convection in the Labrador Sea and in the Nordic Seas. For a positive phase of NAO cold and dry air masses contribute 
(a)

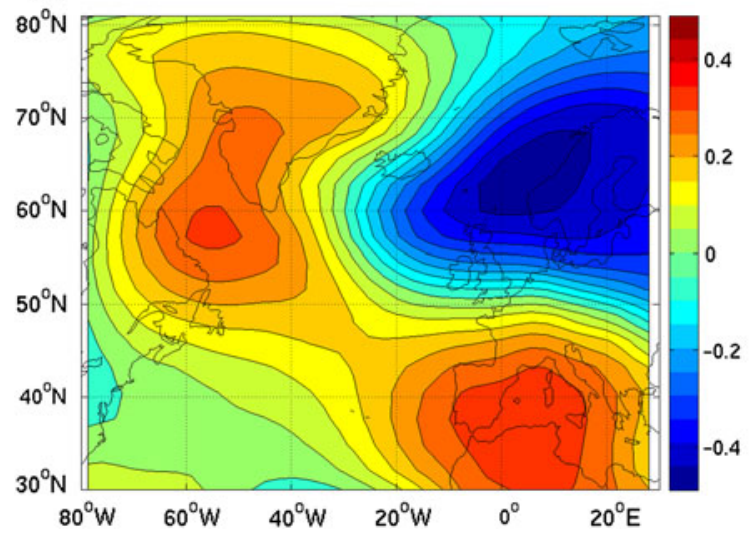

Fig. 13 a Correlation between the band-pass filtered annual poleward heat transport at the Greenland-Scotland Ridge and the sea level pressure (SLP), where SLP leads by 1 year $\mathbf{b}$ negative of EOF3 of the

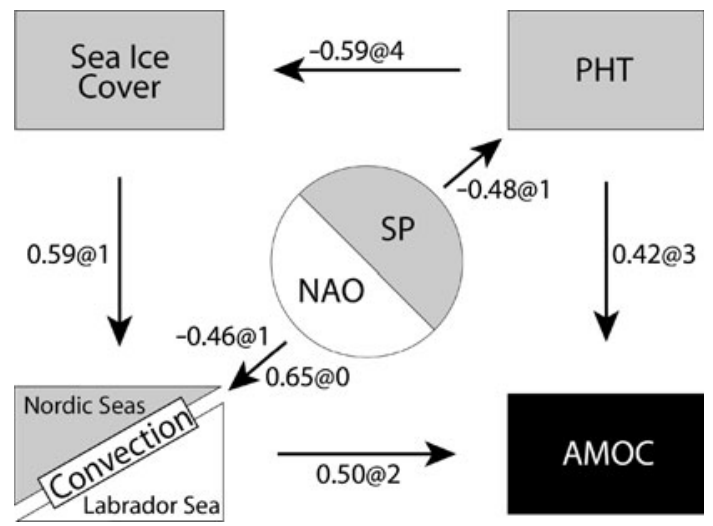

Fig. 14 Schematics of Nordic Seas (gray) and Labrador Sea (white) mechanisms contributing to changes in the modelled AMOC. The circle in the middle represents the atmospheric forcing associated with the North Atlantic Oscillation (NAO) and Scandinavian Pattern (SP), and PHT is the net poleward heat transport across the Greenland-Scotland Ridge. The correlation and time lags (@ in years) between each process is given along the arrows

to favourable conditions for convection, i.e., stronger wind, increased heat loss and less precipitation, in the Labrador Sea. In the Nordic Seas the same effect of the air-sea fluxes are found during a negative phase of NAO, when there are fewer storms bringing warm and moist air masses into the region.

The Nordic Seas contributes with most of the North Atlantic Deep Water originating in the high northern latitudes (two-thirds when entrainment of ambient water downstream the GSR is included), while the rest is a result of deep convection in the Labrador Sea. The variability in the Labrador Sea convection is forced by the local air-sea fluxes related to NAO, where the convection is directly related to the AMOC. The Scandinavian Pattern, is a driver of the ocean's PHT, the overall thermal constraint on northern water mass transformation. Increased PHT is both

\section{(b)}

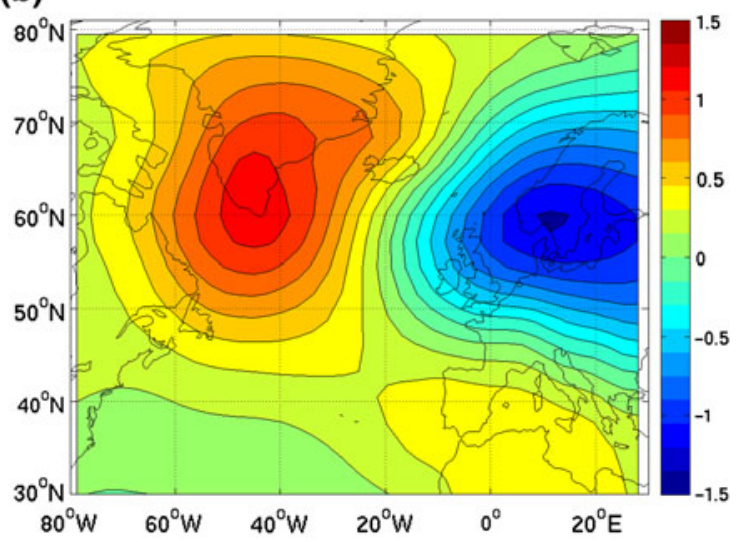

SLP (in hPa std ${ }^{-1}$ ), also called the Scandinavian Pattern explaining $12 \%$ of the sea level pressure variability in the North Atlantic

associated with an increased water mass exchange across the GSR, and a stronger AMOC.

Acknowledgments This work has been supported by the Research Council of Norway through the NorClim (IM and TF) and BIAC (HRL and TE) projects. It also contributes to the DecCen project (TF). This publication is no. A 345 from the Bjerknes Centre for Climate Research. Thanks to $\mathrm{OH}$ Ottera for providing the model data, and to OH Otterå, H Drange, PB Rhines, SM Olsen and J Mignot for discussions and comments. Thanks to the two anonymous reviewers for comments helping to improving the manuscript.

Open Access This article is distributed under the terms of the Creative Commons Attribution Noncommercial License which permits any noncommercial use, distribution, and reproduction in any medium, provided the original author(s) and source are credited.

\section{References}

Barnston AG, Livezey RE (1987) Classification, seasonality and persistence of low-frequency atmospheric patterns. Mon Weather Rev 115:1083-1126

Bentsen M, Drange H, Furevik T, Zhou T (2004) Simulated variability of the Atlantic meridional overturning circulation. Clim Dyn 22:701-720. doi:10.1007/s00382-004-0397-x

Biastoch A, Böning CW, Getzlaff J, Molines JM, Madec G (2008) Causes of interannual-decadal variability in the meridional overturning circulation of the mid-latitude North Atlantic Ocean. J Clim 21:6599-6615. doi:10.1175/2008JCLI2404.1

Bleck R, Rooth C, Hu D, Smith LT (1992) Salinity-driven thermocline transients in a wind- and thermohaline-forced isopycnic coordinate model of the North Atlantic. J Phys Oceanogr 22:1486-1505

Bueh C, Nakamura H (2007) Scandinavian pattern and its climatic impacts. Q J R Meteorol Soc 133:2117-2131. doi:10.1002/qj.173

Chelton DB (1983) Effects of sampling errors in statistical estimation. Deep-Sea Res 30:1083-1101

Clarke RA, Gascard JC (1983) The formation of Labrador Sea water. Part I: Large scale processes. J Phys Oceanogr 13:1764-1778

Cunningham SA, Marsh R (2010) Observing and modeling changes in the Atlantic MOC. Wiley Interdiciplinary Reviews: Climate Change 1:180-191. doi:10.1002/wcc.22 
Cunningham SA, Kanzow T, Rayner D, Baringer MO, Johns WE, Marotzke J, Longworth HR, Grand EM, Hirschi JJM, Beal LM, Meinen CS, Bryden HL (2007) Temporal variability for the Atlantic Meridional Overturning Circulation at $26.5^{\circ} \mathrm{N}$. Science 317:935-937. doi:10.1126/science.1141304

Curry R, Mauritzen C (2005) Dilution of the northern North Atlantic Ocean in recent decades. Science 308:1772-1774. doi: 10.1126/science. 1109477

Curry R, McCartney MS, Joyce TM (1998) Oceanic transport of subpolar climate signals to mid-depth subtropical waters. Nature 391:575-577

Delworth TL, Greatbatch RJ (2000) Multidecadal thermohaline circulation variability driven by atmospheric surface flux forcing. J Clim 13:1481-1495

Delworth TL, Manabe S, Stouffer RJ (1993) Interdecadal variation in the thermohaline circulation in a coupled ocean-atmosphere model. J Clim 6:1993-2011

Déqué M, Dreveton C, Braun A, Cariolle D (1994) The ARPEGE/IFS atmosphere model: a contribution to the French community climate modelling. Clim Dyn 10:249-266

Deshayes J, Frankignoul C (2008) Simulated variability of the circulation of the North Atlantic from 1953 to 2003. J Clim 21:4919-4933. doi:11.1175/2008JCLI1882.1

Deshayes J, Frankignoul C, Drange H (2007) Formation and export of deep water in the Labrador and Irminger Seas in a GCM. DeepSea Res I 54(4):510-532. doi:10.1016/j_dsr.2006.10.014

Dickson RJ, Brown J (1994) The production of North Atlantic Deep Water: sources, rates and pathways. J Geophys Re 99(C6): 12319-12341

Dickson R, Lazier J, Meincke J, Rhines P, Swift J (1996) Long-term coordinated changes in the convective activity of the North Atlantic. Prog Oceanogr 38:241-295

Dickson R, Rudels B, Dye S, Karcher M, Meincke J, Yashayaev I (2007) Current estimates of freshwater fluxes through Arctic and subarctic areas. Prog Oceanogr 73:210-230. doi:10.1016/j. pocean.2006.12.003

Dong B, Sutton RT (2005) Mechanism of interdecadal thermohaline circulation variability in a coupled ocean-atmosphere GCM. J Clim 18:1117-1135

Eden C, Willebrand J (2001) Mechanisms of interannual to decadal variability of the North Atlantic circulation. J Clim 14:22662280

Egbert GD, Ray RD (2000) Significant dissipation of tidal energy in the deep ocean inferred from satellite altimeter data. Nature 405:775-778

Eldevik T, Nilsen JEØ, Iovino D, Olsson KA, Sand $\varnothing$ AB, Drange H (2009) Observed sources and variability of Nordic Seas overflow. Nat Geosci 2:406-410. doi:10.1038/NGEO518

Furevik T, Nilsen JEØ (2005) Large-Scale Atmospheric Circulation Variability and its Impacts on the Nordic Seas Ocean Climate - a review. In: Drange H, Dokken T, Furevik T, Gerdes R, Berger W (eds) The Nordic Seas: An Integrated Perspective, AGU Monograph 158. American Geophysical Union, Washington DC, pp 105-136

Furevik T, Bentsen M, Drange H, Kindem IKT, Kvamstø NG, Sorteberg A (2003) Description and validation of the Bergen Climate Model: ARPEGE coupled with MICOM. Clim Dyn 21:27-51. doi:10.1007/s00382-003-0317-5

Gade HG, Gustafsson KE (2004) Application of classical thermodynamic principles to the study of oceanic overturning circulation. Tellus 56A:371-386

Ganachaud A (2003) Large-scale mass transports, water mass formation, and diffusivities estimated from World Ocean Experiment (WOCE) hydrographic data. J Geophys Res 108(C7):3213. doi:10.1029/2002JC001565
Ganachaud A, Wunsch C (2000) Improved estimates of global ocean circulation, heat transport and mixing from hydrographic data. Nature 408:453-457

Gaspar P (1988) Modeling seasonal cycle of the upper ocean. J Phys Oceanogr 18:161-180

Gregory JM, Dixon KW, Stouffer RJ, Weaver AJ, Driesschaert E, Eby M, Fichefet T, Hasumi H, Hu A, Jungclaus JH, Kamenkovich IV, Levermann A, Montoya M, Murakami S, Nawarath S, Oka A, Sokolow AP, Thorpe RB (2005) A model intercomparison of changes in the Atlantic thermohaline circulation in response to increasing atmospheric $\mathrm{CO}_{2}$ consentration. Geophys Res Lett 32:L12703. doi:10.1029/2005GL023209

Häkkinen S (1999) Variability of the simulated meridional heat transport in the North Atlantic for the period 1951-1993. J Geophys Res 104(C5):10991-11007

Hansen B, Østerhus S (2000) North Atlantic-Nordic Seas exchanges. Prog Oceanogr 45:109-208

Hansen B, Østerhus S, Turrell WR, Jónsson S, Valdimarsson H, Hátún H, Olsen SM (2008) The inflow of Atlantic Water, heat, and salt to the Nordic Seas across the Greenland-Scotland Ridge. In: Dickson RR, Meincke J, Rhines P (eds) Arctic-Subarctic Ocean fluxes, Springer Netherlands, Chap. 1, pp 15-43. doi: 10.1007/978-1-4020-6774-7_2

Hansen B, Hátún H, Kristiansen R, Olsen SM, Østerhus S (2010) Stability and forcing of the Iceland-Faroe inflow of water, heat and salt to the Arctic. Ocean Sci 6:1013-1026. doi: 10.5194/os-6-1013-2010

Holland MM, Bitz CM, Eby M, Weaver AJ (2001) The role of iceocean interactions in the variability of the North Atlantic thermohaline circulation. J Clim 14:656-675

Hurrell JW (1995) Decadal trends in the North Atlantic Oscillation: regional temperatures and precipitation. Science 269(5224): 676-679

Johnson GC (2008) Quantifying Antarctic Bottom Water and North Atlantic Deep Water volumes. J Geophys Res 113:C05027. doi: 10.1029/2007JC004477

Jungclaus JH, Haak H, Latif M, Mikolajewicz U (2005) Arctic-North Atlantic interactions and multidecadal variability of the meridional overturning circulation. J Clim 18:4013-4031

Kraus EB, Turner JS (1967) A one-dimensional model of the seasonal thermocline II. The general theory and its consequences. Tellus 19:98-106. doi:10.1111/j.2153-3490.1967.tb01462.x

Kuhlbrodt T, Griesel A, Montoya M, Levermann A, Hofmann M, Rahmstorf S (2007) On the driving processes of the Atlantic Meridional Overturning Circulation. Rev Geophys 45:RG2001. doi:10.1029/2004RG00166

Langehaug et al (2011) Arctic/Atlantic exchanges via the Subpolar Gyre. J Clim (submitted)

Lozier MS (2010) Deconstructing the Conveyor Belt. Science 328:1507-1511. doi:10.1126/science. 1189250

Lumpkin R, Speer K (2003) Large-scale vertical and horizontal circulation in the North Atlantic Ocean. J Phys Oceanogr 33:1902-1920

Mauritzen C (1996) Production of dense overflow waters feeding the North Atlantic across the Greenland-Scotland Ridge. Part 1: Evidence for a revised circulation scheme. Deep-Sea Res I 43(6):769-806

McManus JF, Francois R, Gherardi JM, Keigwin L, Brown-Leger S (2004) Collapse and rapid resumption of Atlantic meridional circulation linked to deglacial climate changes. Nature 428:834-837. doi:10.1038/nature02494

Medhaug I, Furevik T (2011) North Atlantic 20th century multidecadal variability in coupled climate models: sea surface temperature and ocean overturning circulation. Ocean Sci 7:389-404. doi:10.5194/os-7-398-2011 
Meehl GA, Stocker TF, Collins WD, Friedlingstein P, Gaye AT, Gregory JM, Kitoh A, Knutti R, Murphy JM, Noda A, Raper SCB, Watterson IG, Weaver AJ, Zhao ZJ (2007) Global Climate Projections. In: Solomon S, Qin D, Manning M, Chen Z, Marquis M, Averyt KB, Tignor M, Miller HL (eds) Climate Change 2007: The Physical Science Basis Contribution of Working group I to the Fourth Assessment Report of the Intergovernmental Panel on Climate Change. Cambridge University Press, Cambridge, United Kingdom and New York, NY, USA

Munk W, Wunsch C (1998) Abyssal recipes II: energetics of tidal and wind mixing. Deep-Sea Res I 45:1977-2010

Nilsen JEØ, Gao Y, Drange H, Furevik T, Bentsen M (2003) Simulated North Atlantic-Nordic Seas water mass exchanges in an isopycnic coordinate OGCM. Geophys Res Lett 30(10):1536. doi:10.1029/2002GL016597

Olsen SM, Hansen B, Quadfasel D, Østerhus S (2008) Observed and modelled stability of overflow across the Greenland-Scotland ridge. Nature 455:519-522. doi:10.1038/nature07392

Orre S, Smith JN, Alfimov V, Bentsen M (2009) Simulating transport of ${ }^{129} \mathrm{I}$ and idealized tracers in the northern North Atlantic Ocean. Environ Fluid Mech 10(1-2):213-233. doi:10.1007/ s10652-009-9138-3

Østerhus S, Turrell WR, Jónsson S, Hansen B (2005) Measured volume, heat and salt fluxes from the Atlantic to the Arctic Mediterranean. Geophys Res Lett 32:L07603. doi:10.1029/ 2004GL022188

Otterå OH, Bentsen M, Bethke I, Kvamst $\varnothing$ NG (2009) Simulated preindustrial climate in Bergen Climate Model (version 2): model description and large scale circulation features. Geosci Model Dev 2:197-212

Otterå OH, Bentsen M, Drange H, Sou L (2010) External forcing as a metronome for Atlantic multidecadal variability. Nat Geosci 3:688-694. doi:10.1038/ngeo955

Pickart RS, Straneo F, Moore GWK (2003) Is Labrador Sea Water formed in the Irminger basin? Deep-Sea Res I 50:23-52. doi: 10.1016/S0967-0637(02)00134-6

Pickart RS, Torres DJ, Fratantoni PA (2005) The East Greenland spill jet. J Phys Oceanogr 35:1037-1053

Rhines P, Häkkinen S, Josey SA (2008) Is oceanic heat transport significant in the climate system? In: Dickson RR, Meincke J, Rhines P (eds) Arctic-Subarctic Ocean fluxes, Springer Netherlands, chap 4, pp 87-109. doi:10.1007/978-1-4020-6774-7_5

Rudels B, Friedrich HJ, Quadfasel D (1999) The Arctic circumpolar boundary current. Deep-Sea Res II 46:1023-1062
Salas-Mélia D (2002) A global coupled sea ice-ocean model. Ocean Model 4:137-172. doi:10.1016/S1463.4003(01)00015-4

Schlesinger ME, Ramankutty N (1994) An oscillation in the global climate system of period 65-70 years. Nature 367:723-726

Schott FA, Zantopp R, Stramma L, Dengler M, Fischer J, Wibaux M (2004) Circulation and deep-water export at the western exit of the subpolar North Atlantic. J Phys Oceanogr 34:817-843. doi: 10.1175/1520-0485(2004)034<0817:CADEAT>2.0.CO;2

Segtnan et al (2011) Heat and freshwater budgets for the Nordic Seas computed from atmospheric reanalysis and ocean observations. J Geophys Res (submitted)

Skagseth $\varnothing$, Furevik T, Ingvaldsen R, Loeng H, Mork KA, Orvik KA, Ozhigin V (2008) Volume and heat transports to the Arctic Ocean via the Norwegian and Barents Seas. In: Dickson RR, Meincke J, Rhines P (ed) Arctic-Subarctic Ocean fluxes, Springer Netherlands, chap 2, pp 45-64. doi:10.1007/978-14020-6774-7_3

Smethie WM, Fine RA (2001) Rates of North Atlantic Deep Water formation calculated from chlorofluorocarbon inventories. DeepSea Res I 48:189-215. doi:10.1016/S0967(00)00048-0

Talley LD, Reid JL, Robbins PE (2003) Data-based meridional overturning streamfunctions for the global ocean. J Clim 16:3213-3226

Vellinga M, Wood R (2002) Global climatic impacts of a collapse of the Atlantic thermohaline circulation. Clim Change 54:251-267

Vellinga M, Wu P (2004) Low-latitude freshwater influence on centennial variability of the Atlantic thermohaline circulation. J Clim 17:4498-4511. doi:10.1175/3219.1

Willis JK (2010) Can in situ floats and satellite altimeters detect longterm changes in Atlantic Ocean overturning? Geophys Res Lett 37:L06602. doi:10.1029/2010GL042372

Wunsch C (2002) What is the thermohaline circulation? Science 298:1180-1181

Xu X, Schmitz WJ Jr, Hurlburt HE, Hogan PJ, Chassignet EP (2010) Transport of Nordic Seas overflow water into and within the Irminger Sea: an eddy-resolving simulation and observations. J Geophys Res 115:C12048. doi:10.1029/2010JC006351

Yashayaev I (2007) Hydrographic changes in the Labrador Sea, 1960-2005. Prog Oceanogr 73:242-276. doi:10.1016/j.pocean. 2007.04.015

Zhu X, Jungclaus J (2008) Interdecadal variability of the meridional overturning circulation as an ocean internal mode. Clim Dyn 31(6):731-741. doi:10.1007/s00382-008-0383-9 